\title{
Otonom Araçların Yaygınlaşmasının Önündeki Zorluklar
}

\author{
Difficulties in the Proliferation of Autonomous Vehicles
}

\author{
Yahya TASTTAN $^{1}$ (D), Habib KAYMAZ ${ }^{1,2}$ iif \\ ${ }^{1}$ Marmara Üniversitesi, Elektrik ve Elektronik Mühendisliği, 34722, İstanbul, Türkiye \\ ${ }^{2}$ Mercedes Benz Türk A.Ş., Otobüs Geliştirme,34722, İstanbul, Türkiye
}

Öz

Endüstri devriminin en etkin sonuçlarından biri ulaşım ve taşımacılık alanında içten yanmalı motora sahip otomobillerdir. Günümüzde bir milyarı aşkın sayıdaki konvansiyonel araç, insanoğlunun temel ihtiyaçlarında biri olan hareketlilik ihtiyacını karşılamasına rağmen neden olduğu çevresel etkiler ve trafik kazalarının yol açtığı can ve mal kayıpları sebebiyle halen endüstriyel ve akademik araştırmaların en temel konularından birini oluşturmaktadır. Bu çalışmada, otomotivde Endüstri 4.0' ın doğal sonucu olarak gelişen araç teknolojilerinden biri olan otonom araçların yaygınlaşmasının önündeki zorlukların yanında otonom araçları oluşturan sensör, donanım, yazılım bileşenlerinden bahsedilerek otonominin nassl çalıştığı araştırılmıştır. Bu araçların yaygınlaşmasının önündeki zorluk; teknik yetersizlikler, yüksek geliştirme maliyetleri, satın alma ve işletme maliyetleri, trafik güvenliği ve emniyeti, altyapı yetersizliği, ulaşım fiyatlandırması, durak ve park planlaması ile yolculuk beklentilerinde değişim başlıkları altında irdelenmiştir. Seviye 4 otonom araçların, yüksek maliyet ve sınırlı performansıyla birlikte günümüzde bazı ülkelerde yasal ve ticari araç olarak kullanılmaya başlamıştır. Seviye 5 otonom araçların 2030'larda olgunlaşması beklenirken 2040'larda yaygın ve uygun fiyatlı hale geleceği ve insan güdümlü araçların kullanımının yasaklanabileceği tahmin edilmektedir. Birçok ulaşım ve șehir planlamacısı, araștırmacı ve siyasetçi araç otomasyonunun teknik yapısı ve faydasına inansa da, ortaya çıkacak etki veya sorumlu olanların eylemleri hakkında fikir birliği henüz sağlanmamıştır. Bu çalışmanın sonuç kısmında otonom araçların yaygınlaşmasının önündeki zorlukların üstesinden gelebilmek için bazı önermelerde bulunulmuştur.

Anahtar Kelimeler: Otonom Araç, Araç Teknolojisi, RADAR, Kamera, LIDAR, Yapay Zekâ.

\begin{abstract}
One of the most effective results of the industrial revolution is automobiles with internal combustion engines in the field of transportation. Today, more than one billion conventional vehicles, although they meet the mobility need, which is one of the basic needs of human beings, still constitute one of the most fundamental subjects of industrial and academic research due to the environmental effects and loss of life and property caused by traffic accidents. In this study, in addition to the difficulties in the proliferation of autonomous vehicles, which is one of the developing vehicle technologies as a natural result of Industry 4.0 in automotive, the sensor, hardware and software components that make up autonomous vehicles and how autonomy works are mentioned. Level 4 autonomous vehicles have started to be used as legal and commercial vehicles in some countries with their high cost and limited performance. While Level 5 autonomous vehicles are expected to mature in the 2030s, it is predicted that they will become common and affordable in the 2040s and the use of human-guided vehicles may be banned. While many transport and urban planners, researchers and politicians believe in the technical nature and usefulness of vehicle automation, there is no consensus yet on the impact that will occur or the actions of those responsible. In the conclusion of this study, some suggestions have been made to overcome the difficulties in the proliferation of autonomous vehicles.
\end{abstract}

Keywords: Autonomous Vehicle, Vehicle Technology, RADAR, Camera, LIDAR, Artificial Intelligence.

\section{GİRISS}

Trafikte güvenlik endişeleri, maddi hasarlı ve ölümlü kaza sayılarının yüksekliği, çevresel etkiler, teknolojik gelişmeler ve konfor beklentisinin yükselmesi gibi nedenlerin sebep olduğu etkiler gündelik hayatımızda önemli bir yer tutan kişisel ulaşım araçlarında devrimsel nitelikte değişikliğe yol açmaktadır. Bu kapsamda günlük hayata girmeye başlayan akıllı araçlar, sahip olduğu kontrol üniteleri ve sensörlerin yardımıyla bulunduğu ortamı algılayarak sürücünün daha güvenli ve daha rahat sürüş yapmasını sağlayan araçlardır. Akıllı araçlar ile konvansiyonel araçlar arasındaki en önemli fark akıllı aracın sürücüyü araç kontrolü ve kumandası konusunda desteklemesi veya tamamen kontrolü almasıdır. Akıllı araçlar bunu yaparken sadece sahip olduğu kontrol üniteleri ve sensörlerini değil kablosuz iletişim ağları, uydular, diğer araç ve şehrin altyapısı ile haberleşme imkânlarını da kullanmaktadırlar. Konvansiyonel araçlardan akıllı araçlara geçişte son evreyi temsil eden otonom araçlardan üç temel beklenti vardır;

1. Araç sahibi, yolcu veya kontrol merkezi isteklerinin doğru bir şekilde alınması (İnsan-Makine Etkileşimi, HMI (Human-Machine Interface))

Sorumlu yazar I: Yahya TAȘTAN, Tel: 050731940 85, e-posta: yahyatastan@gmail.com

Sorumlu yazar II: Habib KA'YMAZ,Tel: 0532 28I 86 0I, e-posta: habib.kaymaz@daimler.com

Gönderilme: 22.05.2020, Düzenleme: II.03.202I, Kabul: 28.03.202I 
2. Araç altyapısının (manevra, hız ve fren gibi işlemlerin olması istendiği gibi yapılması için sürüş ve güç kontrol sistemleri ile tüm mekanik ve elektriksel donanımların) eksiksiz sevk ve idaresi

3. Dinamik tam çevre (yol, trafik ve çevresinde bulunan nesnelerin belirlenmesi, sinıflandırılması, hareketlerinin tahmini ile) kontrolü

Otonom araçlarda ilk iki beklenti tam anlamıyla yapılmakta iken üçüncü beklentide halen ciddi eksikler bulunmaktadır. Otonom araçların normal koşullarda güvenilir bir şekilde seyahat edebilmesi için birçok teknik sorunun çözülmesi gerekir [1]. Her kesim tarafından da kullanılabilmesi için milyonlarca kilometreyi bulan test sürüş çalışmalarının başarılı olması gerekmektedir. Piyasadaki araçlar, sağlam ve yüksek güvenlikli yapılmıştır, bu nedenle yeni araç teknolojilerinin bu özelliklere sahip olup olmadığının tespiti için yıllar süren test ve süreçlerden geçmesi gerekmektedir.

Otonom araçların önemli ekonomik sonuçları olacaktır [2]. Otonom araçların güvenli sürüş yapabilmesi için trafik alt yapısının düzenlenmesinden dolayı diğer yatırımlardan daha fazla olması gerekmektedir. Örneğin, birçok otonom araç trafik sıkışıklığı ve kirliliği azaltma, trafik hızını ve yolcu konforunu en üst düzeye çıkarmak veya diğer hedef kullanıcılar için gecikmeyi ve riskleri en aza indirgemek için özel şerit gerektirmektedir.

İkinci bölümde otonom araçların çalışma mantığ ayrıntılı bir şekilde anlatılmıştır. Üçüncü bölümde otonom araçların yaygınlaşmasının önündeki zorluklar anlatılmıştır. Sonuçlar bölümünde ise otonom araçların önündeki bu zorlukları aşabilmek için bazı önermelerde bulunulmuştur.

\section{OTONOM ARAÇLAR}

Otonom araç, çevresini algılama kabiliyeti sayesinde, herhangi bir insan müdahalesi olmadan kendini çalıştırabilen ve gerekli işlevleri gerçekleştirebilen bir araçtır. Bir sürücü olmadan seyahat etmek için sensörlar, kameralar, RADAR (RAdio Detection And Ranging) ve yapay zekayı kullanır. Bazen, özerk (autonomous) yerine otomatik (automated) terimi kullanılmaktadır. Çünkü özerklik kelimesinin elektromekanik anlamından ziyade kendi seçimlerini yapabilen anlamı vardır. Örneğin, "beni işe götür" denildiğinde araba kendi kararını verip markete götürebilmektedir. Tam otomatik bir araba ise ancak emirleri takip eder ki o da kendisini sürmektir. Kendinden sürüş (self-driving) terimi ise araba normal koşullarda çalışabilir ancak acil bir durumda insan müdahalesine ihtiyaç duyabilir anlamına gelmektedir.

\subsection{Otonom Araçların Tarihçesi}

Sürücüsüz bir gelecek çok yakın görünüyor, ancak o noktaya gelmek uzun ve zorlu bir yolculuk olacaktır. Otonom araçların rüyası neredeyse otomobil kadar eskidir. İlk olarak 1925'te Francis Udina, uzaktan kumandalı arabayı icat etti. GM (General Motors) 1956'da otonom bir araba tanitım videosu çekti. Videoda GM, insanların otoyoldaki kontrolü devraldığını, stressiz bir sürüşün tadını çıkardığını ve yolcuların araba ile sesle etkinleşen kontrol özelliklerini gösterdi. 1986'da Ernst Dickens ve Münih Üniversitesi'nden gelen ekip, trafik olmadan tamamen özerk bir şekilde sürülebilen robotik minibüse öncülük etti ve 1987 'de saatte 60 kilometreye kadar hız yaptı [3]. 1990'ların başında, bu ekip Eureka Prometheus projesinde bilgisayar vizyonunu kullanarak çevrede önemli noktalara odaklanan otonom bir binek araç geliştirdi. 1986'da ilk otonom araç olan Navlab1, birden fazla güneş paneli kullanarak saatte 30 kilometre yol ald1. Daha sonra 1990'da Navlab2, her yolda otonom olarak çalışabilen yenilenmiş bir Humvee, yolda saatte 110 kilometrelik hızlara ulaştı. UC Berkeley yolu projesi, özel şeritlerde çalışan araçların otonom takımlarının başarılı çalışmalarıyla ön plana çıktı. Proje aynı zamanda otonom araç endüstrisinde RADAR sistemleri ve araç-araç iletişimi kullanımını iyi bir şekilde sağlamış ve uyarlanabilir hız sabitleme ve acil frenleme gibi ilerlemelere yol açmıştır [4,5]. İlk olarak 2004'te DARPA (The Defense Advanced Research Projects Agency) Mojave Çölü'nde saatte 200 kilometre yol alabilen otonom bir araç gerçekleştirenlere bir milyon dolarlık bir ödül sundu. 2012 yılında, Nevada Motorlu Taşıtlar Departmanı, Google'a ilk kamu otonom araç test lisansını yayınladı. $\mathrm{Bu}$ da artık kamu yollarında otonom bir araç test edebilecekleri anlamına geliyordu [6]. Tesla 2015 yılı sonunda, oto pilot olarak adlandırılan otonom özellikli yazılım paketini tanıttı. 2016 yılına kadar, oto pilotun kendi kendine park edebileceğini ve bir düğme ile nasıl çağrılabileceğini göstermişti. Google, Tesla gibi birçok yeni ve köklü şirket, 2030 gibi yakın bir tarihte tam otonom otomobilleri piyasaya sürmeyi planlamaktadır.

\subsection{Otonom Araç Sinıflandırması}

Şekil 1'de altı otonom sürüş seviyesi tanımlanmaktadır. Tümü insan algısı, planlama ve kontrolü ile başlayan kısma seviye 0 denir. $\mathrm{Bu}$ seviyede, hiç sürüş otomasyonu yoktur [2]. Her şey sürücü tarafından yapılmaktadır. Eğer otonom bir sistem sürücüye uzunlamasına kontrol görevlerini yerine getirerek yardımcı oluyorsa seviye 1 durumudur. Uyarlanabilir hız sabitleyici birinci seviye için iyi bir örnektir. ACC (Adaptif cruise control) sistem, aracın istenilen hızda gitmesini sağlamaktadır. Ancak direksiyon hareketleri için sürücüye ihtiyacı vardır. Böylece boyuna kontrol yapabilir, ancak yanal kontrol yapmak için insana ihtiyaç duyar. Benzer şekilde, şeritte tutma destek sistemleri de seviye 1'dir. Şeritte tutma yardımında, sistem şeridin içinde kalmaya ve sınırlara doğru sürüklendiğinde sürücüyü uyarmaya yardımcı olmaktadır [6]. Seviye 2'de sistem, belirli sürüş senaryolarında yanal ve uzunlamasına kontrol görevlerini yerine getirmektedir. Seviye 2 özelliklerden bazı örnekler GM Super Cruise ve Nissan's Pro Pilot yardımcısıdır. Bunlar hem yan hem 
de uzunlamasına hareketi kontrol edebilir, ancak sürücünün sistemi her zaman izlemesi gerekmektedir. Seviye 3 veya koşullu otomasyon seviyesinde, sistem kontrol görevlerine ek olarak belli bir dereceye kadar yanit olarak nesne ve olay algilama yapabilir [4,5]. Ancak, problem durumunda kontrol sürücü tarafindan alınmalıdır. Seviye 2 ve 3 arasındaki en önemli fark, araç belirli bir durumda sürücünün dikkat etmesinin gerekmemesidir, çünkü araç, sürücüyü müdahale etmek için zamanında uyarabilmektedir. $\mathrm{Bu}$ otonom sisteminin ne zaman bir arıza olduğunu bilmesi her zaman mümkün olmadığından tartışmalı bir otomasyon seviyesidir. Üçüncü seviye sistemlere örnek olarak, yavaş trafikte navigasyon yapabilen Audi A Luxury Sedan verilebilir. Dördüncü seviye sistemler acil durumları kendi başlarına halledebilir ancak yine de gereksiz yere yolun kenarına çekilmelerini önlemek için sürücülerin aracı devralmalarını isteyebilmektedir. $\mathrm{Bu}$ seviyede, yolcular telefonlarını kontrol edebilir veya sistemin acil durumları kaldırabildiğini ve yolcuları güvende tutabildiğini bilerek bir film izleyebilmektedir [3]. Google çatısı altında sürücüsüz araç teknolojileri geliştiren Waymo şirketi, 2015 'te dünyanın ilk seviye 4 aracinı tamamladı. Firefly isimli araba deney ve öğrenme için yapılmıştı fakat seri üretim için bir prototip olarak tasarlanmamıştı. 2018 sonbaharı itibariyle, sadece Waymo bu düzeyde özerkliğe sahip toplu taşıma araçlarında kullanmıştır. Son olarak, beşinci seviyede sistem tamamen otonomdur. $\mathrm{Bu}$, gerekli her koşulda çalışabileceği anlamına gelmektedir. Beşinci seviye, toplumun büyük değişime uğradığı noktadır [7]. Sürücüsüz taksilerin, ihtiyaç duyduğu yerden insanları alması planlanmaktadır. Beşinci seviye için henüz bir örnek yoktur. Öngörülen faydaların çoğu, her koşulda çalışan, güvenli bir şekilde insan veya mal taşıyabilen seviye 5'i gerektirmektedir. Bu çalışmada bahsedilen zorluklar özellikle seviye 5 kast edilmektedir.

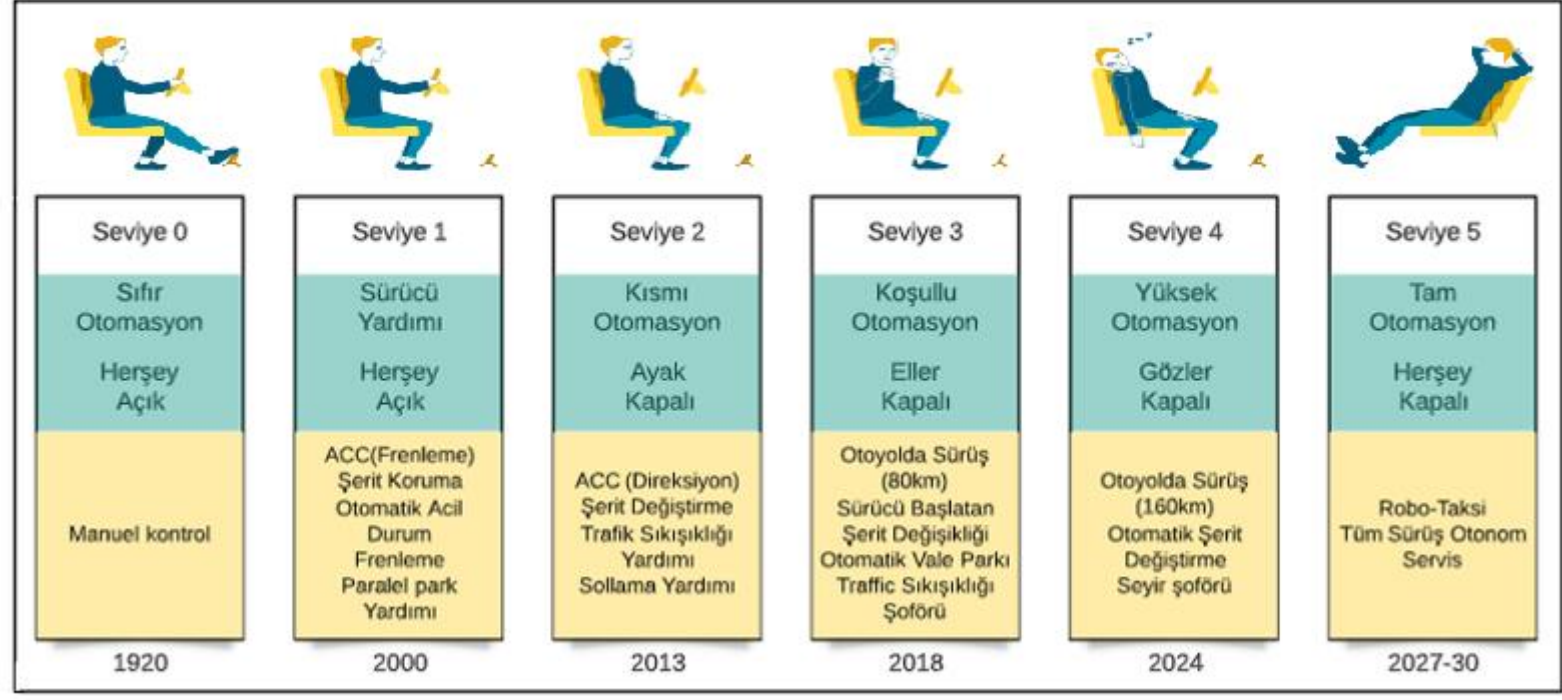

Şekil 1. Otonom sürüş seviyeleri [7]

\subsection{Algı Gereksinimleri}

OEDR, nesne veya olay algilama ve yanıtı (Object and Event Detection and Response) olarak tanımlanmaktadır. Herhangi bir sürüş görevi bir çeşit OEDR gerektirir, yani etraftaki nesneleri tanımlamak, yakınlarda meydana gelen olayları tanımak ve daha sonra buna yanıt vermek için bir yola ihtiyaç vardır. Başka bir deyişle, otonom bir araç yapılmak isteniyorsa, OEDR yapabilmek gerekmektedir. Özellikle, yoldaki herhangi bir eleman için öncelikle ne olduğunu tanımlamak gerekir; bir araba, bir bisikletçi, bir otobüs, vs. İkinci olarak, onun hareketini anlamak gerekmektedir.

İnsanlar belli olayları anlamada gerçekten iyidir. Bununla birlikte, bilgisayar sistemlerinin çevredeki aynı olayları insan kadar çabuk tanıyabilmesi hala zordur [7].
İlk olarak, statik elemanları tanımlamak gerekmektedir. Bunlar yol ve şerit işaretleri, yollarda yaya geçişleri gibi bölgeleri ayıran unsurlar ve okul önleri gibi önemli unsurlardır. Sonra, yol sinırlarını tanımlayan kaldırımlar diğer bir önemli unsurdur [4,5]. İleri veya sola veya sağa gitmeye veya sadece durmaya izin verilip verilmediğini düzenli olarak değiştiren ve bildiren karayolu trafik sinyalleri vardır. Ayrıca hız sınırını söyleyen, yönü gösteren yol işaretleri, bir hastane veya bir okul olduğunu belirten trafik tabelaları vardır. Son olarak, yol engelleri, inşaatın gerçekleştiğini veya barikat kenarı olduğunu söyleyen turuncu koniler vardır. İkincisi, alg1 için gereken dinamik öğeler vardır. Bunlar, bilinçli sürüş kararları vermek için hareketini tahmin etmek gereken unsurlardır. Yoldaki diğer araçları tanımlamak gerekmektedir [6]. Bunlar; kamyonlar, otobüsler, arabalar dört tekerlekli; motosikletler, bisikletler gibi iki tekerlekli hareketini tanımlamak ve tahmin etmek 
gerekmektedir. Bunlar fazla özgürlüğe sahip hareketli sistem olduklarından dolayı tahmin edilmesi daha zordur. Ayrıca etraftaki yayaların hareketlerini tanımlayabilmeli ve tahmin edilebilmelidir. İnsanların hareket ettikleri yoldaki doğal özgürlük nedeniyle araçlardan çok daha düzensiz oldukları bilinmektedir [3]. Algı için nerede olunduğu ve herhangi bir zamanda nasıl hareket edileceği tahmin edilebilmelidir. Konum hareket tahmini için kullanılan veriler GPS (Global Positioning System), IMU (Inertial measurement unit) ve kilometre sayacı sensörlerden gelir ve konumun tutarlı bir resmini oluşturmak için bir araya getirilmesi gerekmektedir. İlk olarak, doğru algıyı gerçekleştirmek büyük bir zorluktur. Algılama ve sinıflamaya modern makine öğrenimi yöntemleri ile yaklaşılabilir, ancak insan seviyesi yeteneğine ulaşmak için güvenilirliği ve performansı artırmak için çok sayıda araştırmaya ihtiyaç vardır $[4,5]$. Büyük veri kümelerine erişim bu çaba için kritik öneme sahiptir. Daha fazla eğitim verisi ile, algılama ve sinıflama daha iyi ve daha doğru performans gösterir, ancak tüm araç tipleri, hava koşulları ve yol yüzeyleri için veri toplamak ve etiketlemek çok pahalı ve zaman alıcı bir işlemdir. İkincisi, algı, sensör belirsizliğine karşı bağışık değildir. Görünürlük zor olabilir veya GPS ölçümleri bozulabilir veya LIDAR (Light Detection and Ranging veya Laser Imaging Detection and Ranging) ve RADAR dönüşlerin konum değerleri açısından gürültülü olabilir. Bu sensörlere dayanan her alt sistem belirsiz ölçümleri hesaba katmalıdır [6]. Bu nedenle, her algılama görevinde sensör belirsizliği ve bozuk ölçümleri barındırmayan alt sistemler tasarlamak kesinlikle çok önemlidir [3]. Ardından kamera veya LIDAR verilerinde emme ve yansıma gibi etkiler vardır. Bunlar, algılama yöntemlerini, nesne konumlarının doğru tahminlerine çözüm bulmakta zorlanan belirsiz bilgilerle karıştırabilmektedir. Sert aydınlatma değişiklikleri ve mercek parlaması veya bazı sensör verilerinin tamamen kullanılamaz hale geldiği GPS kesintileri ve tüneller gibi olaylar da vardır [8]. Algılama yöntemlerinde sensör veri kaybının üstesinden gelmek için Şekil 2'de gösterilen algılama teknolojilerine birden fazla yedek bilgi kaynağı gerekmektedir. Son olarak, sensörlerden gelen giriş verilerinin kalitesini olumsuz yönde etkileyebilecek hava ve yağış vardır. $\mathrm{Bu}$ nedenle, farklı hava koşullarına, örneğin RADAR'la birlikte uyumlu çalışabilen en azından birkaç sensöre sahip olmak çok önemlidir.

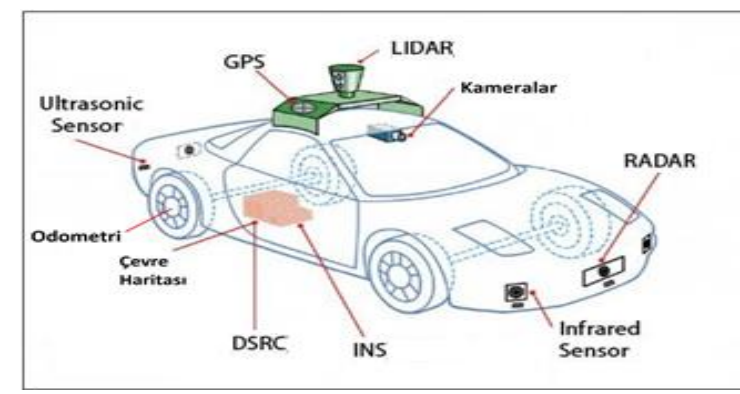

Şekil 2. Otonom araç algılama teknolojileri [20]
ABD'de otonom sürüş için özel kısa mesafe iletişim sistemi kısaca DSRC (Dedicated Short-Range Communications), araçtan araca kısaca V2V (vehicle to vehicle) ve araçtan her şeye kısaca V2X (vehicle-toeverything) iletişiminin uygulanması için teknolojik bir çözüm olarak kabul edilirken, Avrupa'da otonom sürüş işlevlerini uygulayabilecek belirli bir teknoloji henüz görülmemektedir. Avrupa'da 5G'nin, nesnelerin interneti ve otonom sürüş bağlamında bağlantılı sürüş de dahil olmak üzere akıllı endüstrinin çeşitli yönlerini geliştirebilen anahtar teknoloji olduğu varsayılmaktadır. Operasyonel açıdan bakıldığında 5G teknolojisi henüz emekleme aşamasındadır.

Kapsamlı bir 5G ağının teknik uygulamasının çeşitli yönleri hala iyi miktarda araştırma ve geliştirme gerektirmektedir. Halen düzenleyici bir çerçevesi olmayan 5G'nin mevcut teknolojiye kıyasla potansiyel avantajları fazladır. 5G, gerçek zamanlı bilgi aktarımına izin veren bin kata kadar daha yüksek iletim kapasitesi, on kat daha yüksek hız ve on kat daha düşük gecikme süresinin yanı sıra enerji kullanımında bir azalma beklenmektedir. Buna, öngörülen tam erişilebilirlik kapsamının eşlik etmektedir. DSRC'nin savunucuları, DSRC'nin bugün zaten tüm istenen ve gerekli V2V'nin yanı sıra V2X iletişimine izin verdiğini iddia etmektedir. Bununla birlikte 5G'nin teknolojik kapasitelerinin büyük olasılıkla DSRC teknolojisini geçeceği ve geçerli olacağ yönündedir. Otonom araç bağlantısını sağlamada çok çeşitli teknolojiler rol oynamaktadır. Her teknolojinin avantaj ve dezavantajları vardır ve diğer teknolojilerin performansını düşürmeden otonom arabada hepsi birlikte çalışmalıdır. Otomotiv ekosistemi, güvenlik bilincini geliştirmek ve araçlar arasında otonom sürüşün yolunu açmak için, yol kenarı altyapısıyla ve genel çevre ile iletişim kurmak için V2X'i kullanacaktır. 5G bağlantısı, araç operasyonlarını uzaktan teşhis etmek ve izlemek, kablosuz yazılım güncellemeleri yapmak, tele operasyon gerçekleştirmek ve paylaşılan otonom bir filoyu çalıştırarak araç sahipliğini yeniden tanımlamak için kullanılabilmektir.

\subsection{Sürüş Kararları ve Eylemi}

Sürüş kararları verdiğimizde, genellikle üç tür karar alınır. Birinci tip; Zonguldak'tan Sivas'a nasıl gidileceği uzun vadeli bir planlama kararıdır. Bugün kullanılan harita uygulamaları hangi yolların kullanılacağını bildirebilmektedir [7]. Ancak araba kullanmak bundan çok daha fazlasına ihtiyaç duymaktadır. İkinci tip; anlık şerit değiştirme veya kavşakta sola dönme kısa süreli bir sürüş kararıdır. Araç sürmek için bazı acil kararlara veya tepkilere de ihtiyaç vardır. Hızlanmalı mı yoksa fren mi yapmalı eğer öyleyse, ne kadar gibi kararlar verilmelidir. Bu sürüş süresince, tüm senaryolar için sağdan sürüş yapılacağı unutulmamalıdır. Eve giderken bir kavşağa yaklaşıldığı varsayılırsa uzun vadeli planlama aşaması bu kavşaktan sola dönmeyi gerektirmektedir. Burada alınması gereken orta ve kısa vadeli kararlara bakılıısa ilk olarak, trafik ışıklarının 
kontrol edilmelidir. Sola dönmek için, sola dönüş şeridine şerit değiştirme yapmanın gerekip gerekmediğini tanımlamak gerekmektedir [2]. Ardından, bu kavşağa yaklaşırken, yolcuların rahatsız olmaması için yavaşlamayı sorunsuz bir şekilde yapmak gerekmektedir. Daha sonra durma çizgisinden hemen önce, bir yaya geçidinden önce durmak gerekmektedir. Şerit değişikliklerine ve durma yerlerine ilişkin bu kararların tümü kısa vadeli planlama kararlarıdır. Ayrıca, yol boyunca ortaya çıkan durumları düşünmek ve bunlara yanıt vermek gerekmektedir [7]. Arkada başka araçlar varsa veya kavşakta durduysa, ani sola dönüş yapma kararı normal sürüşte hızla ortaya çıkabilecek olası senaryolara göre acil karar kategorisine girer ve planlama sisteminden güvenli tepkiler gerektirmektedir. Sonuç, basit bir sola dönüş senaryosu için bile, farklı zaman ölçeklerinde alınması gereken birçok olası karar vardır. $\mathrm{Bu}$, aynı kavşak geçiși veya farklı durum senaryoları için de konuşmak anlamına gelmektedir. Her senaryoda, gerçek zamanlı olarak değerlendirmek ve sahne hakkında yeni bilgiler elde edildikçe güncellenmek için tutarlı bir dizi seçeneğe ihtiyaç vardır [9].

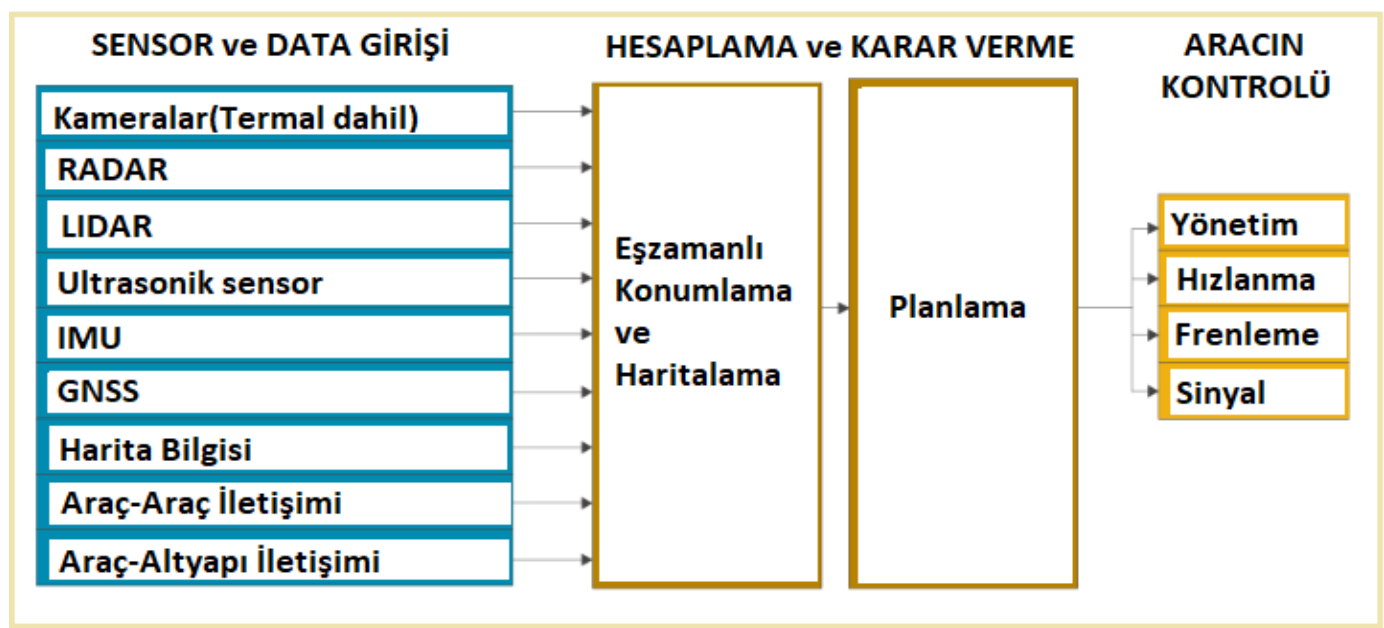

Şekil 3. Otonom araç hesaplama ve karar verme çalışma mantığı [25]

Ayrıca, şerit değiştirme kararları nereye gidileceğini ve hangi araçların konumu göreceli olarak düzenleyeceğini etkilediğinden, görünüşte basit bir sürüş senaryosu bile üç veya dört seviye karar gerektirir ve daha sonra dikkatli araç kontrolü ile yürütülmelidir. $\mathrm{Bu}$ örnekler gerçekten sadece hareket planlaması için gereken sürekli karar akışının hatlarını çizmektedir [10]. Çok düzeyli karar alma zorluklarını aşmanın bir yolu reaktif planlamadir [2]. Reaktif planlamada, konum aracının ve çevredeki diğer nesnelerin mevcut durumunu dikkate alan ve acil eylemler üreten kural kümelerini tanımlanmaktadır. Yani, bunlar sadece mevcut durumu dikkate alan kurallardır gelecekteki durumlar için tahmin değildir. Öngörülü planlamada, ortamdaki araçlar ve yayalar gibi diğer elemanların zaman içinde nasıl hareket edeceği konusunda tahminlerde bulunur. $\mathrm{Bu}$ mevcut durumu ve tahmin bilgilerini tüm kararları tanımlamak için kullanılmaktadır. Öngörülü planlamadaki bazı örnekler şunlardır: "O araba son 10 saniye durdu, muhtemelen birkaç saniye duracak yani onu güvenle geçebilmenin bir yolu var" ya da "yaya dolaşıyor, onlara yaklaşıldı ğı zaman şeride girecekler, yavaşlamak ve yolu geçmeleri için bir şans vermek gerekir”. Görüldüğü gibi, bu düşünmenin daha doğal bir yoludur ve insanların araçları nasıl kullandıklarıyla yakından ilgilidir. Kararları vermeden önce yolda başka nesnelerin nerede olacağını tahmin etmek gerekmektedir. Bununla birlikte, bu tür planlama, ortamdaki diğer aktörlerin eylemlerinin doğru tahminlerine dayanır ve bu da algılama görevlerine önemli bir karmaşıklık katmanı eklemektedir. Bununla birlikte, bir aracın güvenli bir şekilde çalışacağı senaryoları büyük ölçüde genişlettiği için öngörülü planlama, otonom araçlar için baskın yöntemdir.

\subsection{Sensörler ve Kontrol Üniteleri}

Algılama yazılımlarının başarısı Şekil 4'te gösterilen sensör füzyonunun kalitesi ile sinırlıdır. Doğru sensör füzyonu, algılama görevindeki hata oranını azaltacaktır. Sensör, ortamın bazı özelliklerini ölçen veya tespit eden veya zaman içinde bu özellikte değişiklik yapan herhangi bir cihazdır. Şekil 3'te çalışma mantığı verilen otonom araçlar için gerekli sensörler genellikle dahili ve harici sensörler olmak üzere iki gruba ayrılır: Konum, hız, hızlanma, motor tork gibi dahili sensörler cihazın kendisi hakkında bilgi alırlar. Kameralar, menzil sensörleri (k1zıl ötesi sensörü, lazer mesafe bulucu ve ultrasonik sensör), yakınlık sensörleri (foto diyot detektörü, dokunma) ve kuvvet sensörleri gibi harici sensörler çevredeki bilgileri toplamaktadır [12]. Otonom sürüşte en yaygın kullanılan sensör kameradır [4,5]. Kameralar, otonom bir aracın çevresini tam anlamıyla görselleştirmesini sağlamaktadır. Otonom araçlarda kullanılan kameralar çok yüksek çözünürlüğüne sahiptir. Kamera ve bilgisayar, görme yazılımı tarafından işlenen veriler aracın çevresiyle ilgili ayrıntılı bilgileri tanımlamaya 
yardımcı olmaktadırlar. Bazı üreticiler araçlarında şimdilik otonom sürüş için sadece kamerayı kullanmaktadırlar. Ancak mevcut kamera teknolojisiyle seviye 5 henüz mümkün değildir. Kameralar hakkında konuşurken, genellikle üç önemli karşılaştırma metriğinden söz edilmektedir. Çözünürlük, bir görüntü içindeki nokta veya piksellerin sayısını belirten değerdir. Çözünürlük, görüntünün kalitesini belirlemenin bir yoludur [4, 5]. Görüş alanı, sabit bir noktadan bakıldığında gözlerin hem tam önünde hem de etrafında gördükleridir. Bu özellik lens seçimi ve yakınlaştırma ile değiştirilebilmektedir. Bir diğer önemli metrik dinamik aralık, bir görüntüde en parlak ve en karanlık alanlar arasındaki ışık farkı olarak ifade edilmektedir. Dinamik aralığın geniş olması, özellikle gece sürüşlerinde karşılaşılan farklı aydınlatma koşullarında otonom araçlar için görüntünün algılanmasını kolaylaştırmaktadır. Görüş alanı ve çözünürlük seçimi arasında yer alan kameralar ve lens seçimi konusunda önemli bir orantı vardır. Geniş görüş alanı arttırmak istendiğinde belirli bir nesneden 1şığı emen daha az piksel sayısından dolayı, aynı kalitede algılayabilmek için çözünürlüğü artırmak gerekmektedir [3]. Kameraların algı kalitesini etkileyen odak uzaklığı, alan derinliği ve kare hızı gibi özellikleri de vardır. Üst üste binen görüş alanlarına ve hizalanmış görüntü düzlemlerine sahip iki kamera kombinasyonuna stereo kamera denir. Stereo kamera, bir kişinin bir nesneyi görüntüleme prensibi ile aynı şekilde stereo kamera (iki gözlü kamera) kullanarak bir nesneyi birden fazla farklı yönden aynı anda fotoğraflayan bir kameradır. Kameranın pikselinin konum bilgisinden derinlik yönünde bilgi ölçebilen bir kameradır. Sonra 1şık algılama ve değişen sensör anlamına gelen LIDAR kullanılmaktadır [8]. LIDAR sensörleri, bir alanı kaplamak ve geri dönen sinyalleri 3D nokta bulutuna derlemek için saniyede 50.000200.000 darbe göndermektedir. Şekil 5 'te gösterildiği gibi ardışık algılanan nokta bulutlarındaki farkı karşılaştırarak, nesneler ve hareketleri, 250 metreye kadar bir 3D harita oluşturulacak şekilde tespit edilebilmektedir [13]. LIDAR kendi 1şık kaynaklarına sahip aktif bir sensör olduğundan zayıf veya değişken aydınlatma koşullarında çalışırken kameralarla aynı zorluklarla karşılaşmaz [6]. Saniye başına toplanan nokta sayısı ne kadar çok olursa, 3D nokta bulutu o kadar ayrıntılı olabilir. 3D nokta bulutlarının hızlı güncellenmesi dönme hızıyla doğru orantılıdır. Işık kaynağının gücü, tespit aralığını belirlemektedir [7]. Görüş alanı, LIDAR sensörü tarafindan görülebilen açısal boyuttur. Yüksek çözünürlüklü katı hal LIDAR'ları son derece düşük maliyetli ve güvenilir hale gelmektedir. Uygun fiyatlı olmaları otonom sürüşün geleceği için önemli gelişmelerin önünü açacaktır.

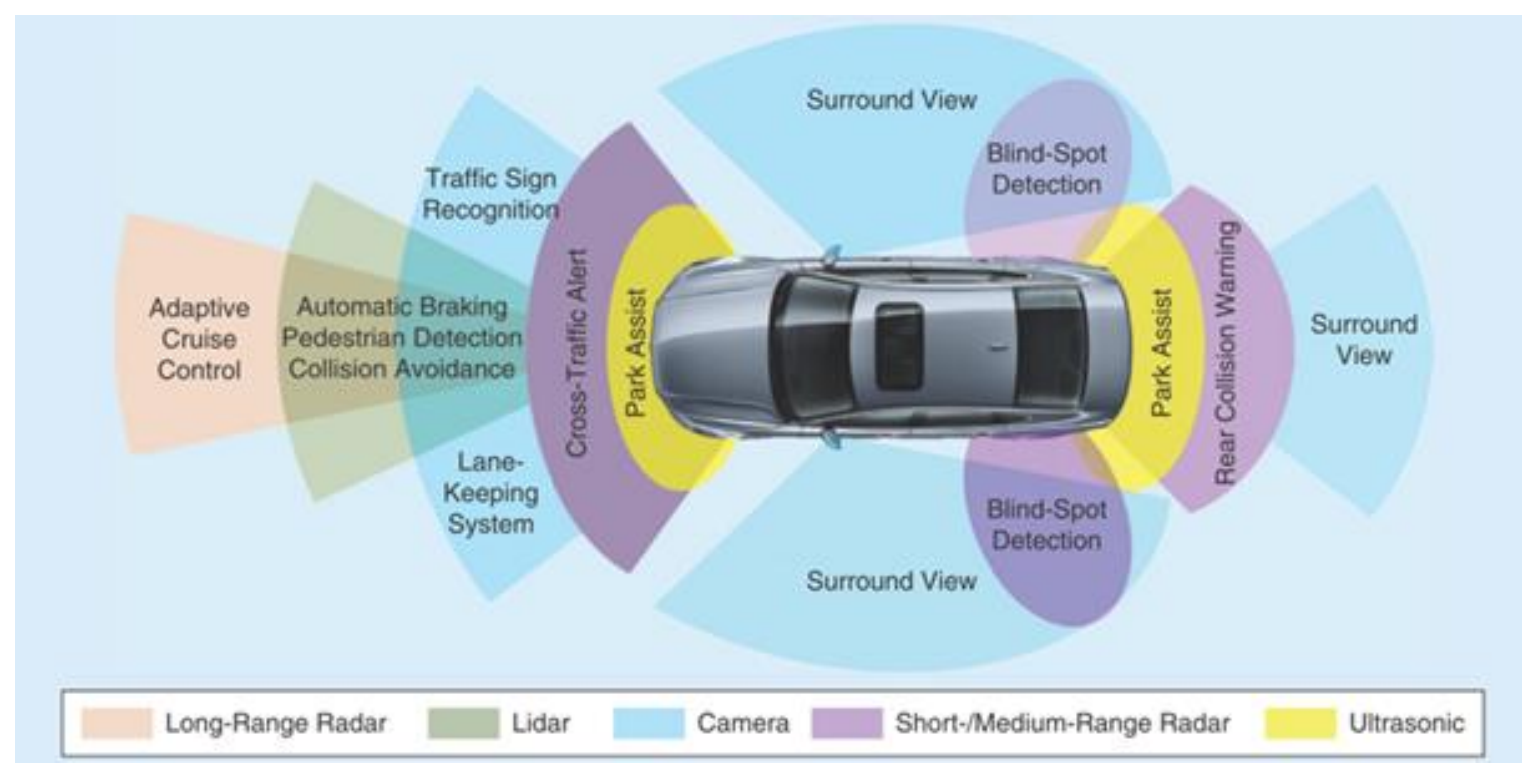

Şekil 4. Otonom araçlarda sensör füzyonu [8] 


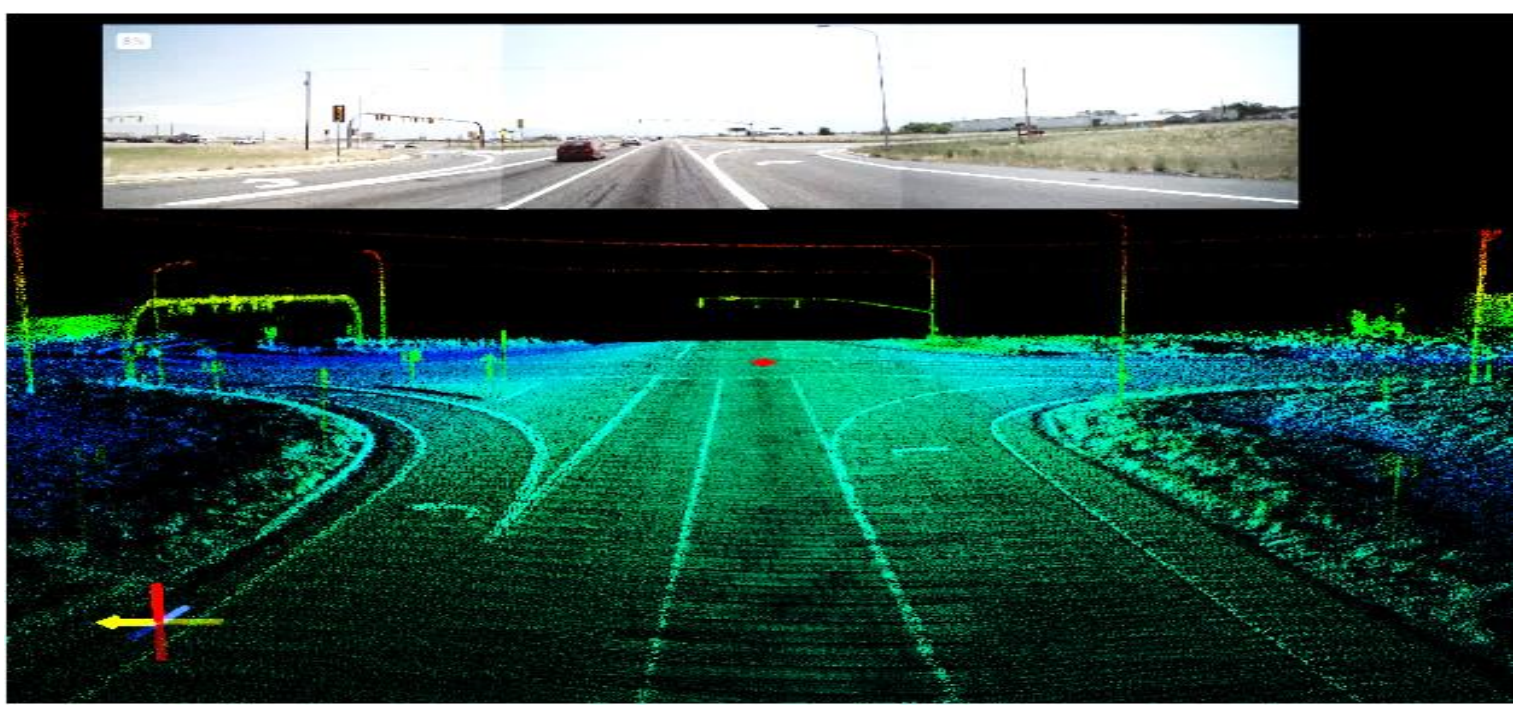

Şekil 5. Toplanan LIDAR görüntüsü ve ilgili fotoğraf görüntüsü [2]

RADAR, mesafe ölçümü için radyo dalgalarını kullanmaktadır. Radyo dalgaları 1 şık hızında hareket eder ve elektromanyetik spektrumun en düşük frekansina sahiptir. RADAR uzun mesafeleri kapsar ve ortamdaki büyük nesneleri iyi bir şekilde algılamaktadır. Manyetik dalgaları kullandığı için yağış ve kar gibi olumsuz havalardan etkilenmez. RADAR, algılama aralığı, görüş alanı, konum ve hız ölçüm doğruluğu gibi temel özelliklere göre seçilir [7]. RADAR 'da geniş açılı görüş alanı istenirse menzilin kısa olmalı ya da tam tersi dar bir görüş alanı ancak daha uzun bir menzil anlamına gelmektedir. Bir sonraki sensör düşük maliyetli ultrasonik veya sonar kısa menzilli sensör oldukları için park senaryoları ve aracın diğer arabalara çok yakın hareketler yapmasında kolaylıklar sağlamaktadır.

Tablo 1. Otonom araçlarda kullanılan çeşitli sensörlerin karşılaştırılması [9]

\begin{tabular}{|l|c|c|c|}
\hline \multicolumn{1}{|c|}{ Sensör } & Ölçü Aralı̆̆ $\mathbf{~ ( m ) ~}$ & Fiyat (\$) & Data oranı (Mbps) \\
\hline Kamera & $0-250$ & $4-200$ & $500-3500$ \\
\hline Ultrasound & $0,02-10$ & $30-400$ & $<0.01$ \\
\hline RADAR & $0,2-300$ & $30-400$ & $0,1-15$ \\
\hline LIDAR & 250'ye kadar & $1.000-75.000$ & $20-100$ \\
\hline
\end{tabular}

RADAR ve LIDAR gibi aydınlatma ve yağış koşullarından etkilenmezler. Tablo 1.'de gösterildiğ gibi sonar ölçebilecekleri maksimum menzil, görüş alanı tespiti ve maliyetlerine göre seçilir.

Aracın yerel ortamdaki göreceli konumunu bilmenin yanı sıra, kullanıcının hedefine doğru bir yol belirleyebilmek için Dünya üzerindeki küresel konumunu da bilmesi gerekmektedir [14]. Varsayılan coğrafi konum belirleme yöntemi, aracın gezegendeki yeri için genel bir referans çerçevesi sağlayan GNSS'dir. GNSS, birkaç metre kadar büyük bir hataya sahip olabileceğinden, konum bilgisi atalet sensörü ve kameranın bilgisiyle kaynaştırılarak iyileștirilebilir. Bu şekilde, konumlandırma bilgisi çok daha kesin olacaktır. [9]. IMU, uzayda hareket halindeki bir cismin üstünde oluşan 3 eksen ivme ve 3 eksen dönme kuvvetini ölçmek için iki tip sensörden oluşur. IMU sistemin ivmelenmesini, açısal hızlanmasını ve dönüklüklerini ölçerek bu verileri sistemin anlık konum verilerine dönüştürmektedir. Son olarak tekerlek kilometre sayacı (Odometri) hareket sensörlerinden gelen bilgileri kullanarak aracın pozisyonun tahmin edilmesi işlemini gerçekleştirmektedir. Araç tekerleklerinde bulunan sensör vasıtasıyla tekerleklerin dönüş sayısı, hızı bilinerek aracın nerede olacağı tahmin edilebilmektedir.

Otonom araçlar için tüm algoritmaları ve süreçleri yürütmek, önemli hesaplamaları yapmak için güçlü işlemciler gerektirmektedir. Tam bir otonom araç, şimdiye kadar oluşturulan herhangi bir yazılım platformundan veya işletim sisteminden daha fazla kod satırı içermektedir. Bilgisayarlar ile hızlı bilgi işleme şu anda endüstri standardıdır [15]. Çoğu şirket, sensörlerine ve algoritmalarına uyan kendi bilgisayar sistemlerini tasarlamayı tercih etmektedir. Bununla birlikte, otonom sürüş için gerekli yapay zekâ destekli yazılımları çalıștıran hazır donanım seçenekleri Nvidia'nın Drive PX/AGX ve Intel\& Mobileye EyeQ 'dur. Otonom sürüş için herhangi bir bilgisayar beyninin hem seri hem de paralel hesaplama 
modüllerine ihtiyacı vardır. Bunlar için belirli bir hesaplama yapmak için özel donanım olan GPU, (Graphic processing unit) FPGA (field-programmable gate array) ve özel ASIC (Application Specific Integrated Circuit) kullanılmaktadır. EyeQ'larda hem görüntü işleme hem de sinir ağı çıkarımı gibi paralelleştirilebilir hesaplama görevlerini hızlandırmak için FPGA'lar vardır. Sistemin verimli çalışması için bütün bileşenlerin doğru şekilde senkronize etmek önemlidir [8]. GPS, son derece hassas zamanlama mevcut olduğunda uygun bir referans saati görevi görebilmektedir. Sensör füzyonunun doğru bir şekilde çalışması için sensör ölçümleri senkron olmalıdır.

\subsection{Donanım Yapılandırma Tasarımı}

Bölünmüş bir otoyolda, araçlar tek yönde gittikleri için izlenecek az şerit fakat hızlı hareket eden ve yüksek yoğunluklu trafik vardır [16]. Bir otoyol sürüşün diğer önemli noktası, eğimin ve virajın az olması fakat dikkate alınması gereken çıkışlar ve birleşmelerin çok olmasıdır. Öte yandan, kentsel durumda, daha az şeritli, orta hacimli ve orta hizlı trafik var, ancak trafik özellikle kavşaklardan her yöne hareket etmektedir [4,5]. Yapılan tüm manevralar için, uzun menzilli algılama için dar açısal görüş alanı sensörlerine ve orta ile kısa menzilli algılama için ise geniş açısal görüş alanı sensörlerine ihtiyaç vardır. Senaryolar daha karmaşık hale geldikçe, yaklaşık 50 metreye kadar kısa ölçekte tam 360 derece sensör kapsama ihtiyacına ve uzunlamasına yönde çok daha uzun menzile gerek vardır. Ayrıca, park senaryolarında yararlı olan sonar gibi daha kısa menzilli sensörler de vardır [17]. Son konfigürasyon seçimi ayrıca çalışma koşulları, arızalar nedeniyle sensör yedekliliği ve bütçeye de bağlıdır. Otonom bir otomobil için hangi sensörlere ihtiyaç duyulduğu konusunda tek bir cevap yoktur. Karayolu ve şehir içi sürüş için hem uzunlamasına hem de yanal durumlar için sensör kapsamı analizi yaparak bir donanım yapılandırmasına göre seçilmelidir.

\subsection{Yazılım Mimarisi}

Araçlar, çevreyi algılamak için bir dizi sensöre, girişi işlemek ve aracın yolunu belirlemek için gelişmiş yazılıma, kararlar üzerinde harekete geçmek için bir dizi aktüatöre ihtiyaç duymaktadır. Ham sensör ölçümleri, otomobilin çevresindeki ortamı anlamak için Şekil 6'da gösterildiği gibi ayrılmış iki modüle aktarılır [7]. Çevre algilama modülünün iki temel sorumluluğu vardır: Otonom aracın uzaydaki mevcut yerini tanımlamak ve sürüş görevi için çevrenin önemli unsurlarını sinıflandirmak ve bulmaktır [4,5]. Bu unsurlar diğer arabalar, bisikletler, yayalar, hayvanlar, yoldaki çukurlar, yol ve yol işaretleri, sürüş hareketini doğrudan etkileyen her şey olabilmektedir. Çevre haritalama modülü, arabalar için sürekli güncellenen ve desimetreye kadar doğru olan etraflarındaki ortamın üç boyutlu bir sunumunu karşılamaktadır. Yüksek kaliteli haritalar, ağaçların, kaldırımların veya ortamdaki diğer fiziksel nesnelerin konumu da dahil olmak üzere yol yüzeyinin ve çevrenin görüntüleri gibi şeyler içermektedir [18]. Hareket planlama modülü, algılama ve haritalama modülleri tarafindan sağlanan tüm bilgilere dayanarak hangi eylemlerin gerçekleştirileceği ve nereye götürüleceğine dair tüm kararları almaktadır.

Hareket planlama modülünün ana çıktısı, aracı hedefe doğru hareket ettiren güvenli, verimli ve konforlu bir planlanmış yoldur. Kontrolör modülü aracın, planlanmış yolda ve trafik durumuna göre istenen hızda seyrini gerçekleştirmektedir.

Aracın direksiyon sistemine monte edilmiş step, servo veya hidrolik motorlar yardımı ile de aracın yönlendirilmesi gerçekleştirilmektedir. Sistem yöneticisi, bütün modüller arasındaki kontrol ve koordinasyonu sağlamaktadır. Sistem sorumlusu, sistemde bulunan herhangi bir sorun ile karşılaştığında güvenlik sürücüsüne hatayı bildirmektedir.

\section{8. Çevre Haritalama}

Yerelleştirme haritası, araba çevrede hareket ettikçe sürekli bir dizi LIDAR noktası veya kamera görüntüsü özellikleri kullanılarak oluşturulmaktadır. Bu harita daha sonra lokalizasyon modülü tarafından GPS, IMU ve tekerlek kilometre sayacı ile birlikte kullanılmaktadır.

Yeni LIDAR, kamera verileri alındıkça, yerelleştirme haritasıyla karşılaştırılır ve yeni verilerin mevcut harita ile hizalanmasıyla araçların konumunun bir ölçümü oluşturulur [6]. Bu ölçüm daha sonra kuşbakış1 tahmin etmek için diğer sensörlar ile birleştirilir ve sonuçta aracı kontrol etmek için kullanılmaktadır. Doluluk 1zgara haritası tüm statik veya sabit engellerin yerini gösteren bir ortam haritası oluşturmak için sürekli bir LIDAR noktası seti kullanmaktadır. Bu harita, otonom araç için güvenli, kazasız yollar planlamak için kullanılmaktadır [7]. Ayrıntılı yol haritası hedefe rota planlamak için tüm düzenleyici unsurlar, düzenleyici özellikler ve şerit işaretleri için ayrıntılı pozisyonlar içermektedir. 


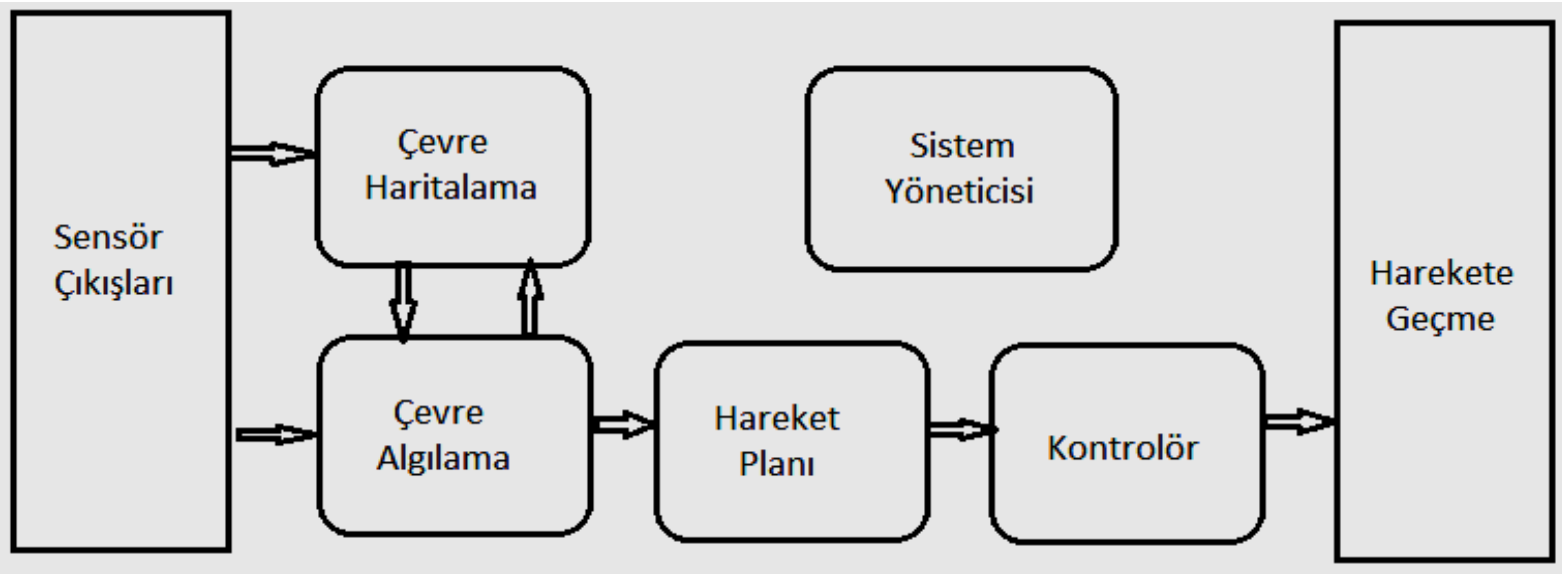

Şekil 6. Yazılım mimarisi [7]

\subsection{Otonom Araçlar için Güvenlik Güvencesi}

2018 başlarında yaya ölümüne yol açan Uber, güvenlik sürücüleri otonom yazılımını izleyerek kapsamlı bir test programına sahipti. Olay gece geniş, çok şeritli bölünmüş yolda meydana geldi ve burada bir yaya bisikletini işaretlenmemiş bir alanda yol boyunca yürümekteydi. Ön soruşturma, olaya yol açan birden fazla eksiklik olduğunu ortaya koydu. Birincisi, güvenlik sürücüsünde gerçek zamanlı kontroller yoktu. $\mathrm{Bu}$ durumda, güvenlik şoförü dikkatsizdi ve o sırada kazazedeyi izlediği iddia edildi. Güvenlik şoförü herhangi bir şey yapıyor olabilirdi ve Uber'in sürücülerinin dikkatini değerlendirmek için araçta bir kontrol yoktu. İkincisi, yazılım algilama sisteminde önemli bir karışıklık vardı. Son altı saniyede ilk tespitin ardından, mağdur önce bilinmeyen bir nesne olarak sinıflandırıldı, daha sonra bir araç olarak yanlış sinıflandırıldı ve daha sonra bir bisiklet olarak yanlış sinıflandırıldi [4,5]. Sonunda, otonom yazilımı tarafindan alınan karar, muhtemelen çok güvenilmez oldukları için tespitleri görmezden geldi [9]. Algı sinıflandırmaları aracı böyle bir nesneyi tamamen görmezden gelmemelidir. Son olarak, çarpışmadan 1,3 saniye önce, Volvo acil fren sistemi yayayı tespit etti ve darbe hızını azaltmak için potansiyel olarak kazazedenin hayatını kurtarmak için frenleri hızla uygulardı. Bununla birlikte, test sirasında aynı anda birden fazla çarpışma önleme sisteminin çalışması güvenli değildir, bu nedenle Uber, otonom moddayken Volvo sistemini devre dışı bırakmıștı [6]. Sonuçta, otonom araç yaya yoluna tepki vermedi ve dikkatsiz sürücü çarpışmayı önlemek için yeterince hızlı tepki veremedi. Güvenlik konusunda titiz ve kapsaml yaklaşımlara ihtiyacı olduğu açıktır ve hem endüstri hem de düzenleyiciler güvenlik sorunuyla başa çıkmak zorundadırlar.

Otonom araç tehlikesi mekanik olabilir, örneğin erken arızaya neden olan bir fren sisteminin yanlış montajı olabilir. Elektriksel tehlikeler hatalı iç kablolar gösterge aydınlatmasının kaybına yol açmaktadır. Otonom yazılımından kaynaklanan hatalar otonom sürüş için kullanılan donanım yongalarının hesaplamalarında yanlışlıklara neden olabilmektedir.
Bu hatalara kötü, gürültülü sensör verileri veya yanlış algılama neden olabilmektedir. Yanlış planlama veya karar verme nedeniyle de tehlikeler ortaya çıabilir, belirli bir senaryo için yanlışlıkla tehlikeli eylemleri seçme neden olabilmektedir [7]. İnsan sürücüsüne geri dönüşün, sürücüye sorumluluğu sürdürmesi için yeterli uyarı vermemesi veya belki de otonom bir aracın kötü niyetli bir varlık tarafindan saldırıya uğraması nedeniyle başarısız olması da mümkündür [3].

Mekanik, elektrik, bilgi işlem donanımı, yazılım, algılama, planlama, sürüş görevi geri dönüşü ve siber güvenlik Şekil 7'de gösterilen düzenli olarak dikkate alınan ana tehlike kategorileridir. Bu tehlikelerin her biri, genel sistem güvenliğini değerlendirirken farklı yaklaşımlar gerektir-mektedir. ABD'de, Ulusal Karayolu Taşımacılığı Güvenlik İdaresi veya NHTSA, (National Highway Traffic Safety Administration) otonom sürüş için güvenlik değerlendirmesini yapılandırmak için on iki parçalı bir güvenlik çerçevesi tanımlamışıır. $\mathrm{Bu}$ çerçeve sadece bir başlangıç noktasıdır. Sektörde halihazırda birden fazla mevcut yöntem ve standardı birleştiren farklı yaklaşımlar ortaya çıkmıştır. Bu çerçeve, 2017 yılında takip edilmesi zorunlu olmayan bir çerçeve olarak önerilmişti [10]. Çerçevenin kendisi, herhangi bir otonom sürüş şirketinin odaklanması gereken veya daha çok odaklanmaya teşvik edilen on iki alan veya unsurdan oluşmaktadır.

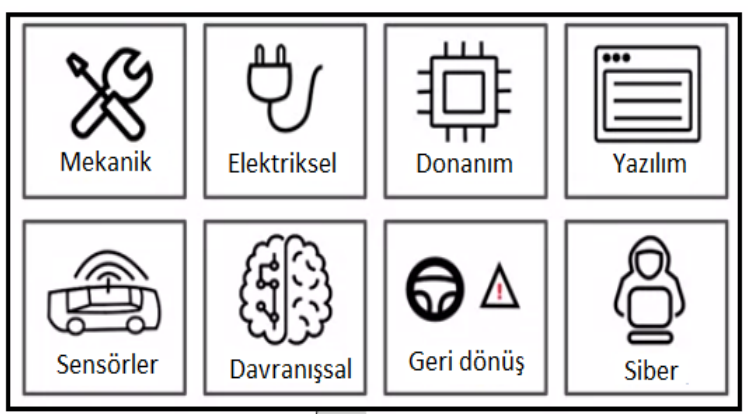

Şekil 7. Başlıca tehlike kaynakları [10] 
İlk olarak, gerçekten tüm çerçeve belgesine nüfuz eden güvenliğe yönelik bir sistem tasarımı yaklaşımı benimsenmelidir. İyi planlanmış ve kontrollü yazılım geliştirme süreçleri esastır ve ilgili yerlerde otomotiv, havacılık ve diğer ilgili endüstrilerden mevcut SAE (Society of Automotive Engineers) ve ISO (The International Organization for Standardization) standartları uygulanmalıdır [4,5]. Otonom yazılım yığınına belirli bileşenlerin dahil edilmesini ve dikkate alınmasını gerektiren otonom tasarımı ve otonom işlevlerinin test edilmesine yönelik yaklaşımları ve arızaların olumsuz etkilerini azaltmanın yollarını kapsayan test ve çarpışma azaltma, onlardan öğrenme sıralanabilir. NHTSA, iyi tanımlanmış bir işlemsel tasarım alanını teşvik ederek tasarımcılar bunun kusurlar1 ve sistemin sinırlamalarından haberdar olmakta ve test veya dağıtımdan önce hangi senaryoların desteklendiğini ve güvenli olduğunu değerlendirebilmektedirler. Daha sonra, alg1 ve çarpışmadan kaçınma için kritik olan iyi test edilmiş bir nesne ve olay algılama ve yanıt sistemini teşvik etmektedir. Ardından, sürücünün uyarıldığı veya otomobilin güvenli bir şekilde güvenli hale getirildiği güvenilir ve kullanışı bir geri dönüş mekanizmasına sahip olmasını teşvik etmektedir. Sürücünün dikkatsiz olabileceğini akılda tutarak bu mekanizmayı geliştirmek şarttır [3]. Yani, bazı düşünceler, bu durumda sistemin asgari risk durumuna nas1l getirileceğine bakmalıdır. Sürüş sistemi ayrıca tüm trafik yasalarına uygun ve bunlara uyulacak şekilde tasarlanmalıdır [7]. Daha sonra, çerçeve tasarımcıları siber güvenlik tehditleri ve sürüş sistemini kötü niyetli ajanlardan nasıl koruyacaklarını düşünmeye tavsiye etmektedir. Son olarak, insan makine ara yüzünün işlevsel ve anlaşılır olmalıdır. Çünkü, araç, makinenin durumunu herhangi bir zamanda yolculara veya sürücüye iyi bir şekilde aktarabilmelidir. Görüntülenebilecek durum bilgilerinin önemli örnekleri, tüm sensörlerin çalışır durumda olup olmadığı, mevcut hareket planlarının ne olduğu, ortamdaki nesnelerin sürüş davranışını nasıl etkilediği gibi bilgiler verilmelidir. Her şeyden önce NHTSA, halk için herhangi bir hizmet başlatılmadan önce güçlü ve kapsamlı bir test programı önermektedir. Bu test üç ortak sütuna dayanabilir; simülasyon, yakın parkur testi ve halka açık yol sürüşü. Daha sonra, bir çarpışma olayı sirasında meydana gelen yaralanma veya hasar miktarını azaltmak için yöntemleri dikkatle değerlendirmek gerekmektedir. Çarpışmalar, kaza enerjisini en aza indirebilecek ve sinırlamalar, hava yastıkları ve çarpışma şiddetine göre yolcu güvenliği standartlarını aşabilecek kamuya açık yol sürüşü ve otonomi sistemlerinin bir gerçeği olmaya devam etmektedir. Ardından, kilitlenme sonrası durum için destek olmalıdır. Otomobil, hızlı bir şekilde, güvenli bir duruma geri döndürülmelidir. Ayrıca, otomatik bir veri kayıt fonksiyonu veya kara kutu kaydedici olmalıdır. Gelecekte belirli bir çarpışmadan kaçınabilecek sistemleri analiz etmek, tasarlamak ve olay sırasında neyin yanlış gittiğini, kimin hata yaptığını sormak için bu çökme verisine sahip olmak çok yararlıdır [11]. Son olarak konuşlandırılmış otonom sistemin yeteneklerini ve sınırlarını daha iyi anlamaları için iyi tanımlanmış tüketici eğitimi ve öğretimi olmalıdır. Bu son adım, otomasyondaki doğal aşırı güveni sağlamak için gereklidir, erken benimseyenler tarafindan gereksiz tehlikelere yol açmaz [10]. Bu şartlar zorunlu değil ama herhangi bir şirketin üzerinde çalışması gereken önerilen alanlardır. NHTSA'nın temel amacı, inovasyonu aşırı derecede kısıtlamadan, otonom giden otomobiller üreten şirketlere rehberlik etmektir. Pazara giriş ortaya çıkmaya başladığında, güvenlik değerlendirmesi için daha kesin gereksinimlerin de ortaya çıkması muhtemeldir.

\subsection{Güvenlik ve Testi için Endüstriyel Yöntemler} Google çatısı altında sürücüsüz araç teknolojileri geliştiren Waymo şirketi, sistemlerini ilk olarak davranış düzeyinde güvenli sürüş sağlamak için tasarlamıştı. Bu, trafik kurallarına uyan, içinde çok çeşitli senaryoları ele alabilen ve araç güvenliğini onunla koruyabilen kararları içermektedir [20]. İkincisi, Waymo sistemlerin yedekli olmasını sağlamaktadır. $\mathrm{Bu}$, bir kaza veya arıza meydana gelse bile araç, arızaların ciddiyetini en aza indirmek ve aracı güvenli bir duruma döndürerek mümkünse sürücüyü devam ettirmek için ikincil bir bileşene veya yedekleme işlemine geçebilmektedir. Daha sonra Waymo, NHTSA tarafından önerilen bir çarpışma durumunda araç içindeki insanlara en az zararı veren sistemleri tasarlamaktadır. Sistem güvenliğini koruyacak şekilde yolcuların araç üzerinde belirli bir düzeyde kontrole sahip olmasına izin vermektedir. $\mathrm{Bu}$, sistemle bir şekilde etkileşime girebilecek sistem tasarımlarını, ilk müdahale ekiplerini, mekaniği, donanım mühendislerini için problemi en aza indirmektir [3]. Bu esas, Waymo'nun tasarım sistemi tarafından güvenliği oluşturur ve sistemin hedeflerinin her bileşen tarafından karşılandığından emin olmak için kapsamlı bir gereksinim tanımı, tasarım yinelemesi ve test sistemine yol açmaktadır. Başlangıçta, Waymo ekibi mümkün olduğunca çok sayıda tehlike senaryosu tanımlamakta ve her biri için olası azaltma stratejilerini, yani bir tehlike oluştuğunda aracın hala güvenli bir duruma ulaşmasını garanti etmektedir. Daha sonra, daha spesifik güvenlik gereksinimlerini tanımlamak için bir tehlike değerlendirme yöntemi kullanmaktadır. Kullandıkları çeşitli yöntemler olası güvenlik riskinin ön analizi, dinamik sürüş görevi açısından yukarıdan aşağıya doğru çalışan bir arıza ağacı tehlike değerlendirmesi ve aşağıdan yukarıya doğru etkiyi değerlendiren bazı tasarım arıza modları ve efekt analizleridir. En sonunda, gereksinimlerin karşılandığından emin olmak için çok sayıda test gerçekleştirmektedir. İlk olarak, simülasyondaki tüm yazılım değişikliklerini günde 17 milyon $\mathrm{km}$ simülasyon seviyesinde test edilmiştir [11]. $\mathrm{Bu}$, sistemin güvenlik gereksinimlerinde beklenen gelişmeleri onaylamak için sürekli çalışan muazzam bir bilgi işlem çabasını temsil etmektedir [4,5]. Bunu 
yapmak için, zorlu senaryolar için tüm yol deneyimlerini benimser ve diğer araçların ve yayaların konum ve hız parametrelerini rastgele değiştiren sistematik senaryo bulanıklığı yapar, böylece aracın güvenli bir şekilde davranıp davranmadığını test edilir. Daha sonra yazılımlarını özel yollarda test ettikleri kapalı saha testi yapmaktadır [21]. UC Berkeley çalışması tarafindan tanımlanan 28 temel senaryo ve Waymo'nun eklediği 19 ilave senaryolar, arka, kavşak, yoldan ayrılma ve şerit değiştirme gibi en yaygın dört kaza tipinden kaçınmak üzere düzenlenmiștir. $\mathrm{Bu}$ kategorilerin her birinin birçok çeşidi vardır, ancak birlikte tüm kazaların yüzde 84'ünden fazlasını oluşturmaktadır. Son olarak, ana Google kampüsünün hemen yakınındaki Mountain View California da dahil olmak üzere ABD'deki birçok farklı şehrin sokaklarında düzenli olarak görülen gerçek dünya testleri yapılmıştır $[4,5]$. Bu test, sıra dışı olan ve öncelikle test sirasında insanların otonom yazılımını izlemesini sağlayan dinamik sürüş görevi geri dönüş stratejisine dayanan daha fazla vakayı belirlemelerine olanak tanımaktadır.

\section{OTONOM ARAÇLARIN YAYGINLAŞMASININ ÖNÜNDEKİ ZORLUKLAR}

Otonom otomobillerin yakın gelecekte eşi benzeri görülmemiş bir ekonomik, sosyal ve çevresel bir değişime yol açacağı düşünülmektedir. Ancak otonom araçların yaygınlaşmasının önünde bazı zorluklar vardır. Bunlar; teknik yetersizlikler, yüksek geliştirme maliyetleri, satın alma ve işletme maliyetleri, trafik güvenliği ve emniyeti, altyapı yetersizliği, ulaşım fiyatlandırması, durak ve park planlaması ile yolculuk beklentilerinde değişimdir.

\subsection{Teknik Yetersizlikler}

Otonom aracın, tüm yol, hava ve trafik koşullarında tüm sürüş senaryolarına uyarlanabilmesi için tasarlanması en büyük teknik zorluktur. Belki de tamamen otonom bir sürüş deneyimi sağlamada kamera teknolojisinin temel kisitlarından biri, insan beyninin görülmeyen şey hakkında bir belirleme yapması yerine kameraların sinir ağlarından karmaşık tahminlere dayanmasıdır. $\mathrm{Bu}$, araç içi bilgisayar sistemiyle doğal olarak sınırlı iki faktör olan önemli miktarda eğitim ve işleme gücü gerektirmektedir. $24 \mathrm{GHz}$ RADAR sensörleri sadece sinırlı bir çözünürlük sunabilmektedir. Otomobilin dünyayı görmesini sağlarlar, ancak gerçekte boyanmış resim biraz bulanıktır ve çok sayıda spesifik tehlikeyi tanımlamak ve bunlara tepki vermek sorunlara yol açmaktadır.

LIDAR teknolojisi başlangıç olarak, saniyede bir milyon ölçüm yapabilmektedir. $\mathrm{Bu}$ ölçümleri eyleme dönüştürülebilir veri setleri haline getirmek büyük miktarda işlem gücü gerektirmektedir. LIDAR karmaşıktır ve çoğu hareketli parçalardan dolayı hasarlanmalara karşı daha savunması haldedir. Mevcut kablosuz teknoloji hala bazı teknik engeller sunarken, bu sistemlerin verimliliğini en üst düzeye çıkarmak zor olabilir. Daha önce belirtildiği gibi $5 \mathrm{G}$ teknolojisinin iletişimdeki gecikme ve güvenilirlik gibi birçok önemli zorluğun üstesinden gelmesi beklenmektedir. Tablo 2'te gösterildiği gibi otonom araçta bulunan sensörlerin bazı sınırları aşağıda sıralanmıştır:

- Aşırı hava koşulları (şiddetli yağmur, kar veya sis): Kameraların, LIDAR'ın maksimum menzilini ve sinyal kalitesini azaltır (görme keskinliği, kontrast, aşırı görme karmaşası). Otonom görme sistemleri kısa menzil iletişim aktarımlarını az da olsa etkilemektedir.

- Araçta aşırı kir veya fiziksel engeller (kar veya buz gibi): Kameralar, LIDAR, RADAR için maksimum aralık ve sinyal kalitesi (keskinlik, kontrast, görüş alanının fiziksel tıkanması) azalmaktadir.

- Karanlık veya düşük aydınlatma: Kamera sistemlerinin maksimum menzilin azalması veya karışması, sinyal kalitesini (keskinliği, kontrast, harici 1 şı kaynaklarından olası parlama) azaltmaktadır.

- Büyük fiziksel engeller (binalar, arazi, sık bitki örtüsü, vb.): Kameralar, RADAR, LIDAR için görüş hattını, küçük engeller ise iletişim için maksimum sinyal aralığını azaltabilir.

- Yoğun trafik: Kameralar, RADAR, LIDAR için görüş hattına müdahale eder veya azaltır. Aşırı miktarda sinyal/ mesaj nedeniyle iletişime de müdahale edebilmektedir.

Tablo 2. Her sensörün otonom araçlar için geçerli olduğu temel çalıșma özelliklerinin özeti [11]

\begin{tabular}{|l|l|l|l|l|}
\hline \multirow{2}{*}{ Performans ölçütü } & \multirow{2}{*}{ İnsan } & \multicolumn{3}{|c|}{ Otonom Araçlar } \\
\cline { 3 - 5 } & İyi & İyi & İyi & Kamera \\
\hline Nesne algılama & İyi & Kötü & Orta & Irta \\
\hline Nesne sınıflandırması & Orta & İyi & İyi & Orta \\
\hline Mesafe tahmini & İyi & Kötü & İyi & İyi \\
\hline Kenar algılama & İyi & Kötü & Kötü & İyi \\
\hline Şerit takibi & İyi & İyi & Orta & Orta \\
\hline Görüş alanı & Orta & İyi & Orta & Kötü \\
\hline Kötü hava performansı & İyi & İyi & Orta \\
\hline $\begin{array}{l}\text { Karanlık veya düşük aydınlatma } \\
\text { performansi }\end{array}$ & Kötü & Yok & Yok & Yok \\
\hline $\begin{array}{l}\text { Trafikteki diğerleri ile iletişim } \\
\text { kurabilme ve altyap1 }\end{array}$ & Kötü & & \\
\hline
\end{tabular}




\subsection{Yüksek Geliştirme Maliyetleri}

Satışa sunulan araçlarda seyir kontrolü, tehlike uyarısı ve otomatik paralel park etme gibi Seviye 2 ve 3 teknolojileri bulunmaktadır. Tesla'nın Autopilot'u 2016 yılında ölümcül bir çarpmaya neden olduktan sonra ertelenmesine rağmen, sınırlı koşullarda otomatik direksiyon ve hızlanma sunmaktadır [17]. Mevcut en gelişmiş otonom araç Waymo seviye 4 geliştirme ve test aşamasındadır. Birçok şirket, belirli koşullarda otonom araçları test eden Seviye 4 pilot projelere sahiptir [25]. Ancak bu ilerlemeye rağmen, araçların tüm normal koşullar altında otonom olarak çalışabilmesi için birçok teknik iyileştirmeye ihtiyaç vardır [26].

Her ne kadar mevcut teknolojiler araçların otoyollarda bağımsız olarak çalışmasına izin verse de, iyi havalarda $\% 95$ çalışabilirlik sağlamak zor olacaktır. \%99,9 kullanılabilirlik elde etmek (özellikle y1l boyunca nadir gidilen yerler) çok daha zor olacaktır [28]. Bir aracı yollarda kullanmak, araçlar, yayalar, bisikletliler, hayvanlar, trafik işaretleri, yol çizgileri ve çukurlar da dahil olmak üzere diğer nesnelerin tespiti ve olayını algilamak zordur. Bu zorluk nedeniyle, Şekil 8'de gösterildiği gibi otonom araçlar uçaktan en az 4 kat fazla kod satırına sahip olacaktır. Böyle bir yazılım üretmek, test etmek, onayını almak zaman alıcı, zor ve maliyetlidir. Başarı oranını arttırmak için sürekli yeni bilgilere ihtiyaç duymaktadır. Otonom araç pazarının gelişmesi teknolojik ilerlemeye ve arz talep ilişkisine bağlıdır. Anketlerde ortaya çıkan önemli tüketici endişelerinin giderilmesi gerekmektedir [27]. Araçlarının istenen tüm noktalara ulaşamaması halinde yolcular erişim endişesiyle karşılaşacaklardır [3].

\subsection{Satın Alma ve İşletme Maliyetleri}

Otonom araçlar Tablo 3'te özetlenmiş çeşitli ekipman ve hizmetler gerektirmektedir. Şu anda, Seviye 2 ve Seviye 3 için gerekli özellikler genellikle birkaç bin dolara mal olmaktadır. Navigasyon ve güvenlik hizmetlerine yıllık abone ücretleri 150-750 dolar gibi ek masraf gerektirmektedir. Otonom araçlarda bir arıza oluşması ciddi sonuçlara neden olacağından otonom araçların uzmanlar tarafından kurulan sağlam ve yedekli elemanlara ihtiyaç olacaktır. Mevcut gelişmiş sürücü destek sistemi sensörleri (kameralar, RADAR ve ultrason) hassas oldukları için yaklaşık çarpışma hasarı iki kat maliyeti getirmektedir. Bu tür ufak hasarlar bile en az 3.000\$ masraf gerektirdiği için otonom araçların araç onarım maliyetlerini artıracağını göstermektedir. Yeni çıkan her teknoloji gibi otonom araçlar çok yüksek fiyatlı olacaktır. Belki düşük fiyatlı modellerde standart hale gelmesi yillar sonra olacaktır [22]. Otonom araçlar diğer araçlardan birkaç bin dolar ve yıllık servis, bakım ve onarım maliyetlerinde de yüzlerce dolar daha fazla pahalı olacaktır.

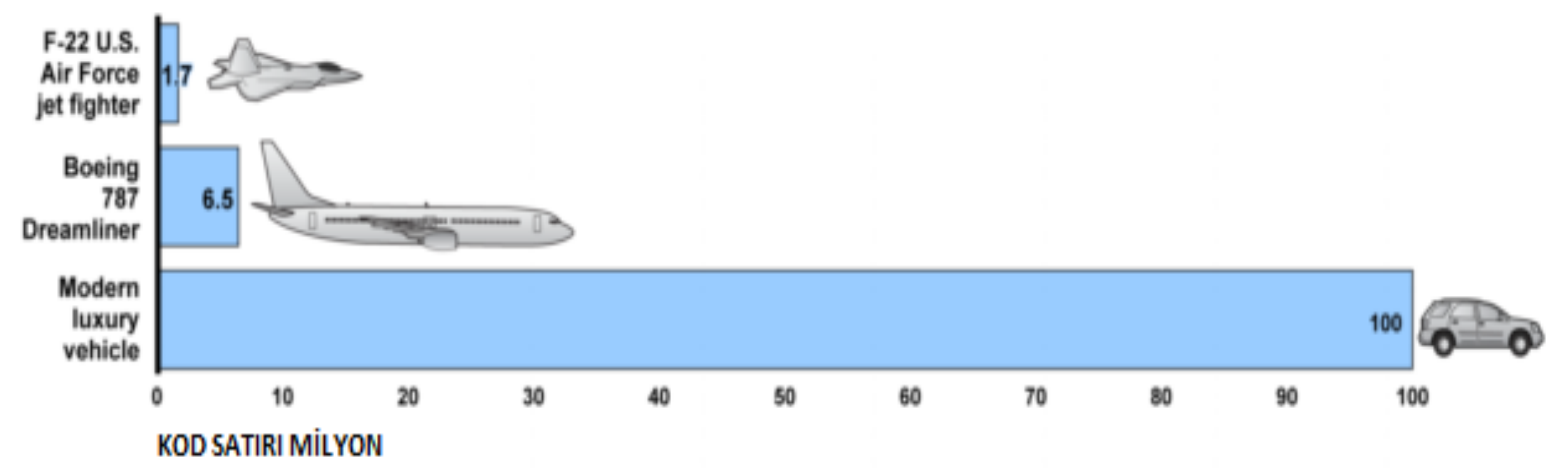

Şekil 8. Uçak ve otomobil yazılım kodları karşılaştırması [3]

Tablo 3. Otonom araç ekipmanları ve servis gereksinimleri

\begin{tabular}{|l|l|}
\hline Tüm Otonom Araçlar için & Toplu Taşıma Otonom Araçları için \\
\hline *İnsan-Makine etkileşimi (HMI) & *Sevkiyat ve filo yönetimi. \\
*Sensörler (optik, kızı̈lötesi, RADAR, lazer vb.). & *İşletme ve sigorta. \\
*Otomatik kontrol (direksiyon, fren, sinyal) & *İsletme giderleri. \\
*Yazılım, sunucular ve güç kaynakları. & *Güvenlik. \\
*Kısa menzilli araç-araç iletişimi ağlar, ayrıca & *Sik temizlik ve onarımlar. \\
haritalar, güncellemeler ve yol raporları. & *Yolcu yüklemesi için gecikmeler ve boş araç km. \\
*Navigasyon GPS sistemleri ve özel haritalar. & \\
*Kritik eleman bakımı, onarımı ve testi. & \\
& \\
\hline
\end{tabular}




\subsection{Trafik Güvenliği ve Emniyeti}

İyimserler, insan hatası kazaların \%90'ina sebep olduğundan, otonom araçların kaza oranlarını ve sigorta maliyetlerini $\% 90$ oranında azaltacağ iddialarına karşın yeni riskler göz ardı edilmektedir:

- Risk almanın artışı: Yolcular kendilerini daha güvende hissettiklerinde daha fazla risk alma eğilimindedirler. Örneğin, otonom araç yolcuları emniyet kemeri kullanımını azaltabilir ve diğer yol kullanıcıları aşırı güvenli teknoloji olarak tanımlayarak daha az ihtiyatlı olabilirler [11].

- Artan toplam araç seyahati: Konforu artırarak otonom araçlar toplam araç seyahatini ve dolayısıyla çarpışma riskini artırabilir [4,5].

- Geleneksel güvenlik stratejilerine daha az yatırım, gelecekteki sürücü güvenliği teknolojisinin de gelişmesine engel olabilir [7].

$\mathrm{Bu}$ yeni riskler otonom araçların çalışmasına engel olursa, tahmin edilen $\% 90$ 'lık kaza azaltma oranına ulaşılamayacaktır. Sivak ve Schoettle, en gelişmiş otonom araçlar ile normal bir sürücünün çarpışma oranlarının aynı olacağı ve otonom ve insan güdümlü araçlar karıştığında toplam kazaların artabileceğini iddia etmektedir [27]. Groves ve Kalra, sadece kaza oranlarını \%10 azaltsalar bile otonom operasyonun toplam araç yolculuğunu artırması durumunda toplam kazaların artacağını söylemektedirler. Otonom araçlar dışarıdan gelecek saldırılara karşı korumalı değildir. Bir deneyde, araştırmacılar yol kenarındaki trafik işaretlerinde küçük bir oynamanın yazılımın yanlış okumasına neden olduğunu gösterdi. Bilgisayar korsanları ve yazılım tasarımcıları arasında otonom araçların kontrolü üzerinde maliyet ve risk artıracak bir silahlanma yarışı olacaktır.

\subsection{Altyapı Yetersizliği}

Otonom araçların sürüşü için gerekli yol işaretleri, tünel gibi yerlerde iletişimin kesilmemesi için transponderler gibi ek altyapılara ihtiyaç duyabilirler [7]. Otonom sürüs, daha dar trafik șeritlerine izin verebilir, ancak kamyon ve otobüsleri gidebilmesi için bu şeritler uygun değildir. Şekil 9'de gösterildiği gibi otonom araçlarla birlikte tüm araç trafiğinin otonom olduğu bölgelerde trafik 1şıklarına olan ihtiyaç ortadan kalkabilir [19].

\subsection{Ulaşım Fiyatlandırması}

Otonom araçlar, yatay mimari teşvik ederek ve boş araç seyahatini artırarak araç hareketini ve trafik sorunlarını, \%10-30 oranında artabildiği gibi tam tersi seyahat süresini ve araç işletme maliyetlerini azaltarak trafik sorunlarını \%10-30 oranında azaltabilir [29]. Şu anda hiçbir yol kullanım ücreti ödemeyen otonom araçların sayısının artmasıyla bu ücretler alınacaktır [26].

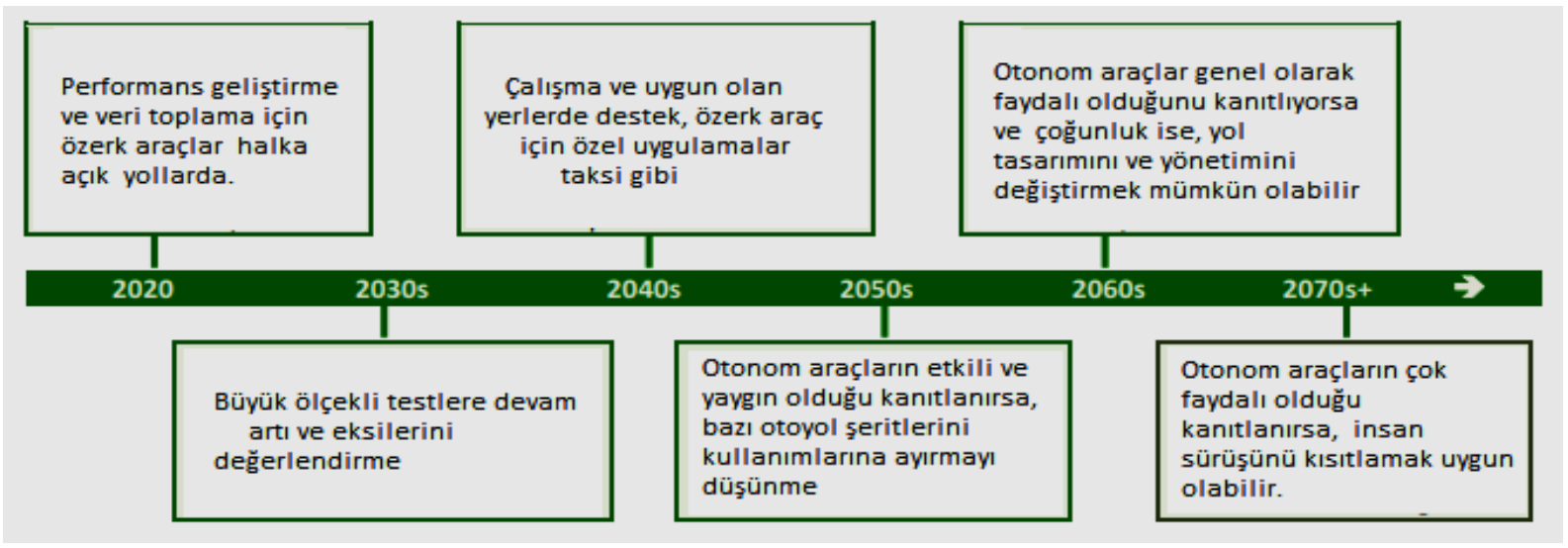

Şekil 9. Otonom araç planlama ihtiyaç zaman çizelgesi [9]

\subsection{Durak ve Park Planlaması}

Toplu taşımayı kolaylaştırmak için, şehirlerin uygun yolcu yükleme ve boşaltmalarını sağlayacak durakların yapılması gerekmektedir $[18,20]$. Bu durakların iş yapabilmesi için caddelerde olması ve yakınında genellikle uygun boş bir alan bulunması gerekmektedir. Elektrikli otonom araçlar için enerji ihtiyaçlarını karşılayabilecekleri şarj istasyonları ve araç temizleme ve bakım hizmetleri içeren özel alanlara ihtiyaç duyacaktır [30]. Özel araçtan toplu taşımaya geçiş, toplam araç sayısını ve park ihtiyaçlarını azaltabilir ve özel araç sahipleri, araçlarını yolcuları bıraktıktan sonra eve dönecek şekilde programlayabilir ancak bu, trafik sorunlarını artıracak ve yolcuların ne zaman geleceği konusunda gecikmeler belirsizlik katacaktır.
Çoğu yolcu park yerinin yakın olmasını isteyecektir, bu da durak noktalarından bir veya iki kilometre içinde park yeri gerektirecektir. Bu, daha fazla park alanı sunarak kentsel park taleplerini azaltır, ancak ortadan kaldırmaz.

\subsection{Yolculuk Beklentilerinde Değişim}

Otonom araç seyahatinin etkilerini üzerine yapılan bir ankette, birçok kişinin otonom araçların seyahatlerini önemli ölçüde etkilemesini beklememesine rağmen değişiklik öngörüsünün düşüşten ziyade seyahatleri arttıracağ1 yönündedir [15]. Fleming ve Schoettle, sürücülerin toplu taşıma yerine özel araç kullanmasının trafikteki araç sayısına \%11 ekleme yapacağını tahmin etmektedir [16]. 
Trommer, otonom araçların 2035 yılına kadar toplam araç seyahatini \%3-9 oranında artıracağını tahmin etmektedir [4]. Taiebat, Stolper ve $\mathrm{Xu}$, otonom araçların sadece zengin ailelerde özel araç seyahatini \%2-47 oranında artıracağını tahmin etmektedir [23]. Mevcut kurallarla, otonom araçların da trafiğe çıkmasıyla trafik sıkışıklığı, karayolu altyapı maliyetleri, kaza olayları ve kirlilik emisyonları sonucunda trafikte geçen süreyi en az \%10-30 artıracağını göstermektedir. [21]. Geleneksel fosil yakıtlı otomobil sahipleri genellikle yaklaşık 16.000 $\mathrm{km}$ yol alıyorlar ve elektrikli otomobil sahiplerinin düşük yakıt maliyetleri nedeniyle biraz daha fazla araba kullanmaları muhtemeldir [22]. Elektrikli otonom araç sahipleri, düşük fiyatlı elektrik yakıtından dolayı daha çok otomobil seyahati yapmak isteyeceklerdir. Miller ve Kang göre kamu politikaları değiştirilerek toplu taşıma otonom araçların uygun fiyatlı ve yolların özel şeritli olması trafikteki araç sayısı azaltacaktır [24].

Bireysel seyahati azaltma teşvikleri uygulanmadığ sürece, toplam araç seyahati ve trafik sorunları artabilir. Yolda kalma süresi artarsa, kazalar ve kirlilik emisyonları artabilir. Toplu taşıma araçların gerekli ihtiyaçlarının giderilmesi için park istasyonlarına ve yolcu indirme ve bindirme için duraklara ihtiyacı olacaktır [20,30]. Takım halinde sürüş için bazı faydalar maliyetlidir ve yalnızca otoyollarda mümkün olan özel şeritler gerektirmektedir.

İşgücü toplu taşıma maliyetlerinin çoğunu temsil ettiğinden, özerk teknolojiler transit hizmet sağlama maliyetlerini önemli ölçüde azaltabilir. Belirli bir bütçeyle, toplu taşıma firmaları daha küçük araçlar ve yolcuları hedeflerine daha yakın teslim eden yollar kullanarak daha çok hizmet verebilirler.

Daha ucuz taksi hizmetleri, kapıdan kapıya veya otobüs duraklarına ve tren istasyonlarına uygun hareketlilik sağlayabilir. $\mathrm{Bu}$ özellikle, toplu taşımanın yaygın olmadığ1 kırsal alanlarda etkili olmalıdır. Gelir, maliyet verimliliği ve politik desteği azaltarak geleneksel hizmet talebini azaltabilir ve servis kalitesinin düşmesine neden olabilirler. Toplu taşıma araçlarından otonom araçlara geçişlerin trafik sıkışıklığını, kazaları ve kirlilik emisyonlarını artıracağı düşünülmektedir.

\section{SONUÇLAR}

Endüstri devriminin yaşantımıza kattığ 1 otomobillerin neden olduğu çevresel etkiler, trafik kazalarının yol açtığı can ve mal kayıplarını azaltma çabaları konfor beklentisinin eklenmesiyle otonom araçları kaçınılmaz kılmaktadır. Birçok insanın kısa sürede uygulamaya girmesini umduğu bu teknolojinin yaygın hale gelmesinin önünde halen teknik yetersizlikler, yüksek geliştirme maliyetleri, satın alma ve işletme maliyetleri, trafik güvenliği ve emniyeti, altyapı yetersizliği, ulaşım fiyatlandırması, durak ve park planlaması, yolculuk beklentilerinde değişim gibi üstesinden gelinmesi gereken ciddi zorluklar mevcuttur.
Aşağıdaki verilenler etkin stratejiler, otonom araç avantajlarını en üst düzeye çıkarmaya ve sosyal maliyetlerini en aza indirmeye yardımcı olacaktır.

- Ulaştırma sistemi verimliliği ve eşitlik gibi sosyal hedefleri vurgulama.

- Güvenlik ve verimlilik için yeni teknolojileri test etme ve düzenlemenin teşvik edilmesi.

- Araç test ve kazaları gibi önemli verilerin sorumlu bir şekilde toplanmasını, saklanmasını ve paylaşılmasını sağlama.

- Otonom araçların etik ve topluluk hedeflerine göre programlanmasını zorunlu kılma.

- Trafikte etkin fiyatlandırma ve araç önceliği gibi araç trafiğini en uygun seviyelere getirmek için politikalar uygulama.

- Toplu taşıma otonom hizmetlerin uygun fiyatlı olmasını sağlamak ve özel ihtiyaçları olan insanlara yardım etmek.

- Toplu taşıma istasyonlarını çok modlu ulaşım sistemlerine entegre etme.

- Sokakları yeniden tasarlamak ve kentsel yaşana bilirliği artırmak için araç trafiğini azaltma.

- Kentsel yoğunlukları ve yeşil alanı artırmak için park etme gereksinimlerini azaltma.

\section{KAYNAKLAR}

[1] Smith, W., (2012), Automated Vehicles are Probably Legal in the United States, Center for Internet and Society, Stanford, CA.

[2] Bhise, V. D. (2012). Ergonomics in the automotive design process, Boca Raton. FL: Taylor\&Francis Group, LLC.

[3] Grush, B. (2016), Driverless Cars Ahead: Ontario Must Prepare for Vehicle Automation. Residential and Civil Construction Alliance of Ontario (RCCAO).

[4] Trommer S., Autonomous Driving: The Impact of Vehicle Automation on Mobility Behaviour, Institute of Transport Research www.ifmo.de, (2016).

[5] WSJ ,Why Your Next Car May Look Like a Living Room, Wall Street Journal, www.wsj.com, (2017).

[6] AAA (annual reports), Your Driving Costs, American Automobile Association https://publicaffairsresources.aaa.biz

[7] Lawson, S., (2018), Tackling the Transition to Automated Vehicles, Roads that Cars Can Read Report III, European Road Assessment Association

[8] Montemerlo, M. (2008), Junior: the Stanford entry in the urban challenge. J. Field Robot. 25,569-597.

[9] Bacha, A. (2008). Odin: Team VictorTango's entry in the DARPA Urban Challenge. J. Field Robot. 25, 467-492.

[10] Frehse, G. (2008), PHAVer: algorithmic verification of hybrid systems past HyTech. Int. J. Softw. Tools Technol. Transfer 10, 263-279.

[11] Ackerman, E., (2017). Toyota's Gill Pratt on SelfDriving Cars and the Reality of Full Autonomy. 
Spectrum, International Institute of Electrical [22] M Katrakazas C, Quddus M, Chen WH, Deka L. Engineers www.ieee.org

Real-time motion planning methods for autonomous road driving: Most advanced and future research directions. Transp Res Bölüm C: Emerg Technol. 2015; 60: 416-442. (www.cpuc.ca.gov/avcissued)

[13] Dickey, S. (2008). Development of hardware in the loop simulation and paramics/VS-PLUS integration. Technical report UCB-ITS-PRR-200829, California PATH research report

[14] Eykholt, K. Robust Physical-World Attacks on Deep Learning Models. Cryptography and Security, https://arxiv.org/abs/1707.08945, (2018).

[15] Fleming, K., Singer, M. Energy Implications of Current Travel and the Adoption of Automated Vehicles, National Renewable Energy Laboratory; at www.nrel.gov/docs/fy19osti/72675.pdf, (2019).

[16] Groves, D., Kalra, N. Enemy of Good: Autonomous Vehicle Safety Scenario Explorer, Rand Corporation at www.rand.org/pubs/tools/TL279.html. (2017).

[23] Morteza Taiebat, M., Stolper S., Xu M., (2019), Forecasting the Impact of Connected and Automated Vehicles on Energy Use: A Microeconomic Study of Induced Travel and Energy Rebound, Applied Energy, Vol. 247, pp 297-308

[24] Papa, E., ve Ferreira A. (2018), Sustainable Accessibility and the Implementation of Automated Vehicles: Identifying Critical Decisions. Urban Science, Vol. 2, No. 1

[25] Naik G, Choudhury B, Park JM.

IEEE 802.11bd \& 5G NR V2X: Development of Radio Access Technologies for V2X Communication.IEEE Erișimi. 2019. s. 7016970184.

[17] Hyatt, K. Toyota had the Most Autonomous Vehicle Disengagements, Road Show at www.cnet.com/roadshow/news/2019-californiaself-driving-disengagement-report-baidu-waymocruise. (2020).

[18] Knight, W., Snow and Ice Pose a Vexing Obstacle for Self-Driving Cars. Wired Magazine, at www.wired.com/story/snow-ice-pose-vexingobstacle-self-driving-cars. (2020).

[19] Litman, T., (2020), Autonomous Vehicle Implementation Predictions Implications for Transport Planning. Victoria Transport Policy Institute, 24 March 2020

[26] Autonomous Vehicles, University Of Toronto https://www.coursera.org/specializations/selfdriving-cars, (2020)

[27] Schoettle, B., Sivak, M. (2014), A Survey Of Public Opinion About Autonomous And SelfDriving Vehicles In The U.S., The U.K., And Australia, Report UMTRI-2014-21, Transportation Research Institute, University of Michigan

[28] Owsley, C. ve McGwin, G., Jr. (2010), Vision and driving. Vision Research, 50(23), 2348-2361

[29] Urmson, C. (2008), Autonomous driving in urban environments: Boss and the Urban Challenge. J.Field Robot. 25, 425-466.

[20] Marsden, G., Iain Docherty, I., Robyn Dowling, R., (2020), Parking Futures: Curbside Management in the Era of New Mobility' Services, Land Use Policy, Vol. 91

[21] Millard-Ball, A., (2016), Pedestrians, Autonomous Vehicles, and Cities, Journal of PlanningEducation and Research, pp. 1-7

[30] Zhang, W., Kaidi Wang, K. (2020), Parking Futures: Shared Automated Vehicles and Parking Demand Reduction Trajectories in Atlanta, Land Use Policy, Vo. 91 